\title{
Roots of Ergativity in Africa (and Beyond)
}

\author{
Antje Casaretto, Gerrit J. Dimmendaal, Birgit Hellwig, Uta Reinöhl \& Gertrud Schneider-Blum \\ University of Cologne / University of Freiburg
}

\begin{abstract}
In the literature, it is often assumed that ergative constructions originate in passive constructions. The present contribution explores the likelihood of such a passive-toergative analysis for one language (Tima, Niger-Congo, Sudan), showing that this analysis cannot be substantiated and suggesting an origin in active constructions instead. This study is situated in its areal context (outlining similarities to split case marking systems across the region, especially in the Southern branch of Eastern Sudanic) and against the background of discussions in the Indo-Iranian family (from where the passive-to-ergative hypothesis presumably spread).
\end{abstract}

Keywords: alignment, marked nominative, split ergativity, passive, prominence, causation, volitionality

\section{Introduction}

Ergativity is not a common phenomenon across Africa. For example, Creissels and Good (2018: 709) remark in their recent typological survey that "[t]he ergative type of core syntactic role coding is exceptional among African languages." The first detailed account of (split) ergativity in an African language only became available in 1988, when Andersen described such an alignment system for Päri (a Nilotic language of South Sudan). ${ }^{1}$ The following examples, taken from Andersen (1988), illustrate this phenomenon. The intransitive $S$ argument (ùbúr 'Ubur' in 1) and the transitive $\mathrm{O}$ argument (dháagj 'woman' in 2 and 3) are unmarked for case, while the transitive A argument (ùbúrrì 'Ubur' in 3) is marked for ergative case by means of a suffix. In Päri, this pattern correlates with constituent order: the transitive A argument is only marked for ergative case when it occurs in postverbal position (as in 3), but not in preverbal position (as in 2).

$$
\begin{array}{ll}
\text { ùbúr } & \text { á-túuk' } \\
\text { Ubur } & \text { C-play } \\
\text { 'Ubur played.' (Andersen 1988: 292, ex. 2a) }
\end{array}
$$

$$
\begin{array}{lll}
\text { ùbúr } & \text { dháag̀̀ } & \text { á-yáan }-\grave{\varepsilon} \\
\text { Ubur } & \text { woman } & \text { C-insult-3S }
\end{array}
$$

'Ubur insulted the woman.' (Andersen 1988: 294, ex. 6a)

$$
\begin{array}{llc}
\text { dháag̀̀ } & \dot{a} \text {-yàan } & \text { ùbúrr-ì } \\
\text { woman } & \text { C-insult } & \text { Ubur-ERG } \\
\text { 'Ubur insulted the woman.' (Andersen 1988: 292, ex. 3a) }
\end{array}
$$

\footnotetext{
${ }^{1}$ Buth (1981) was probably the first to use the label "ergative" with respect to an African language, namely for Luwo, another Nilotic language. More recently, Storch (2014: 189) confirms this alignment system for this language. In other cases, more recent research shows that languages categorized as having split ergativity in earlier work (e.g, König 2017) turn out to have different alignment patterns, e.g., Shilluk, which has been reanalyzed as a language with a marked nominative system (Remijsen and Ayoker 2018).
} 
Following on from these first accounts, (split) ergativity has been described for other African languages, many of them from the Nilo-Saharan family and spoken in East Africa, in an area extending to the east and south of the Nuba Mountains in Sudan. Our interest is in this overall region (which we delimit in section 3), and we present a detailed case study of split ergativity in one language of this region (Tima, a Niger-Congo language of Sudan) (discussed in section 4). Synchronically, the structural properties of the case systems are very similar across the region: many languages manifest a split in case marking where the agent ${ }^{2}$ argument of a transitive verb is either left unmarked or else marked with an ergative case marker (in Tima, by means of a proclitic $N=$; in Päri above, by means of a suffix $-\varepsilon /-e$ or $-1 /-i)$. This split is grammatically conditioned, in that ergative marking is obligatory in some contexts (in particular, with postverbal agents) and ungrammatical in others (usually with preverbal agents). Speakers, however, do have a choice whether to present a proposition in the form of, e.g., AVO or AOV (without case marking of the agent), as in example (2) above, or OVAERG (with case marking of the agent), as in example (3) above. That is, from this perspective, these languages can alternatively be characterized as having optional ergativity (see McGregor 2010 on different types of asymmetries in case marking systems).

The focus of our presentation is diachronic, and we engage specifically with the hypothesis that ergatives originated in passives. Our interest in passives is partly motivated language-internally (as the marking of instruments or causes in the passive construction bears formal similarities to the marking of agents in the ergative construction), and partly cross-linguistically (as passive origins of ergatives have been proposed for many languages, including for languages of our area of interest). We do not find evidence for a passive origin in our study, though, and we argue instead for an origin in active constructions. Given that there are no diachronic records available, our account has to remain speculative to some extent. We nevertheless consider it plausible for two reasons. First, all the available evidence speaks against a passive origin in these languages. And second, the hypothesis of a passive origin cannot be upheld for many other languages, including Indo-Iranian (i.e., for the language family that presumably provided the main evidence for the original passiveto-ergative hypothesis).

This paper is structured as follows: Section 2 sets the scene by summarizing the passiveto-ergative hypothesis, with a focus on Indo-Iranian languages; section 3 turns to Africa and introduces split ergativity as an areal phenomenon; section 4 presents a case study of one of the languages of this area, Tima; and section 5 concludes this paper.

\section{Diachrony: The passive-to-ergative hypothesis}

There exists a considerable body of literature on possible sources for ergative constructions; in particular, it is often assumed that they developed from passive constructions (see McGregor 2017: 452f. for a discussion and contextualization of the literature). This assumption probably originated within the Indo-Iranian family: it has been argued that passives gave rise to ergatives in this family, with the availability of historical sources lending considerable force and credibility to such claims. Contemporary specialist literature is more skeptical in this regard, though. For example, Haig (2008: 30) notes for Indo-Iranian that it often seems to be mere terminological tradition to label the source construction as 'passive', without necessarily committing to a syntactic 'passive' analysis. And McGregor (2017: 452) even remarks that "[o]blique markers in passives, possessive perfects, and nominalizations are the most overrated sources of ergative case markers" (see also Aldridge 2017).

But while the cross-linguistic evidence against a passive origin is mounting, the literature still contains so many allusions to a passive origin that the impression arises that it is a wellestablished fact, rather than a hypothesis to be verified or falsified. This includes contemporary research within Indo-Aryan (one of the sub-branches of Indo-Iranian; the others are Iranian and

\footnotetext{
${ }^{2}$ Throughout this paper, we use the labels 'agent' and 'patient' in the sense of generalized proto-roles ('protoagent' and 'proto-patient', cf. Dowty 1991) or macro-roles ('actor' and 'undergoer', cf. Van Valin and LaPolla 1997).
} 
probably Nuristani), e.g., the majority of contributors to a recently edited volume (Dahl and Stroński 2016) assume the passive-to-ergative development as the standard view (for a critical review, see Reinöhl 2018). And it also includes the area of interest to us. In her overview of case systems in Africa, König (2008: 95-137) summarizes and discusses the available literature on the emergence of ergative case in Western Nilotic languages, defending a passive origin for one of the subgroups. In particular, she cites two types of evidence, which are both highly relevant to our own research.

One type of evidence is the form of the ergative construction, in particular a) the formal identity of the ergative marker to an adposition introducing peripheral participants (including causes) and b) the unusual constituent order of O[patient]VA[agent] (which could be explained if we assumed a passive origin in the form of S[patient]V Oblique[agent]). Both formal properties are found in many languages of the area (see section 3), including Tima (see section 4). In our case study of Tima, we therefore pay special attention to the evidence for and against a passive origin. To foreshadow our discussion there, we find no evidence for an origin in a passive construction, and instead argue for an extension of instrument (marking causes) in active sentences to agent. It is likely that similar extensions account for the development of ergative markers in other languages of this region, too (see Dimmendaal 2014a for a discussion of ergative case markers originating from instrumental and genitive case markers in Nilo-Saharan).

The other type of evidence is cross-linguistic, as "[w]orldwide, one main source for ergative markers are agent markers which encode peripheral agents in passive clauses [...]" (König 2008: 130). This is an important piece of evidence, given that our interest is in languages without attested historical sources. That is, all proposed diachronic scenarios have to remain speculative, and cross-linguistic tendencies assume an important role in evaluating their probability or improbability - including the scenarios that we present for Tima in section 4.3. Before embarking on our analysis of Tima, we therefore briefly summarize the current state of research within IndoIranian. This focus on Indo-Iranian is motivated by the availability of historical sources in that family, i.e., if it can be shown that passives gave rise to ergatives in this family, this will have repercussions for our analyses of languages without historical sources. And it is motivated by the fact that the passive-to-ergative hypothesis seems to have been proposed first for Indo-Iranian, from where it spread to the analyses of ergatives in other languages.

Ergative constructions developed in the early attested history of Indo-Iranian, and ergativity remains a feature characterizing numerous modern Indo-Iranian languages. Example (4) from Hindi illustrates such a present-day ergative construction. The patient (lassī 'lassi') is unmarked and controls agreement, whereas the agent (larke 'boy') is marked by the postposition ne 'ERG'.

$$
\begin{array}{lll}
\text { larke=ne } & \text { lassī } & p \bar{\imath} \\
\begin{array}{l}
\text { boy.OBL.SG.M=ERG } \\
\text { 'The boy drank lassi.' }
\end{array} & \text { lassi.DIR.SG.F } & \text { drink.PFV.SG.F }
\end{array}
$$

In earlier literature, it was argued that the Indo-Iranian ergative constructions originated in passive constructions. Presumably, this analysis was influenced by the morphological form of the verb used in ergative constructions: the Indo-European "past passive participle" (PPP) in *-to-/-no(Indo-Iranian -ta-/-na-). Present-day passive constructions in Indo-European languages like English or German involve (partially) cognate forms of this PPP, e.g., English The food is/gets cooked, German Das Essen wird gekocht (both with the Proto-Indo-European affix *-to-); or English The ball is/gets thrown (with *-no-). The same form also appears in the Indo-Iranian ergative constructions: having undergone both extension and erosion, forms like $p \bar{\imath}$ 'drink.PFV.SG.F' in example (4) above go back to this PPP. However, this formal overlap is the only similarity with modern passive constructions in Western European languages, and there is no other indication that the source construction of the Indo-Iranian ergative was a passive (see, e.g., Benveniste 1952, Klaiman 1978, Hock 1986, Peterson 1998, Haig 2008). 
The very earliest instances of the PPP used predicatively with overt arguments occur in subordinate function (see Casaretto and Reinöhl, submitted). In terms of case marking, agents were optionally expressed by instrumental or genitive case (Jamison 1979), whereby the instrumental becomes the default in later stages of Old Indo-Aryan, while the genitive marks the ergative in Iranian. The following two examples show PPPs with overt agents in the instrumental: example (5) from Vedic Sanskrit (Indo-Aryan), and example (6) from Gāthic Avestan (Iranian). Note that the PPP occurs in subordinate function in both examples (as reflected by the free translation) - it is only over time that the PPP starts to be used as a main predicate with two overt arguments if transitive.

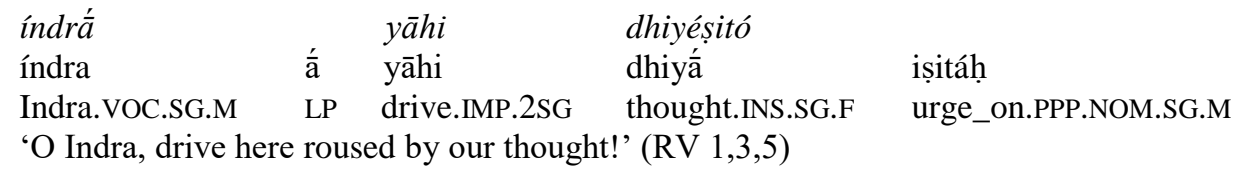

$$
\begin{aligned}
& \begin{array}{lllll}
y \bar{a} & \ldots & \text { fraoxtā } & \ldots & \text { daeuuāišca }
\end{array} \\
& \text { REL.NOM.PL.N proclaim.PPP.NOM.PL.N god.INS.PL.M_and man.INS.PL.M_and } \\
& \text { 'which (are) proclaimed by gods and men' (Y. 48,1, example taken from Jamison 1979: } \\
& \text { 138) }
\end{aligned}
$$

Importantly, the source constructions do not meet the definition of a 'passive', as it is understood in modern linguistic theory, i.e., as the label for the derived voice in an asymmetric voice alternation, which is used to suppress or background the agent in a transitive event. Morphologically, the derived status of a passive construction is typically reflected in the greater morphological complexity of the verb in comparison to the active voice. Syntactically, the derived status is instantiated by the optionality or even ungrammaticality of expressing the agent. If expressed, the agent is morphologically marked in comparison to its encoding in an active voice construction, such as by an oblique case or by an adposition. By contrast, the patient has subject properties such as bearing nominative case or being unmarked for case, or by controlling agreement.

By this definition, the source constructions in Indo-Iranian cannot be considered passive constructions. We briefly summarize the main arguments here (and refer the reader to a detailed discussion of the evidence, e.g., to Haig 2008 for Iranian).

First, the source construction cannot be considered a derived voice from another, active, voice: there is no active, basic counterpart. Morphologically, the construction is less complex than other (finite) verbal forms, if anything.

Second, the source construction is not specialized for transitive expressions. Instead, it occurs just as productively with intransitives, where it has an active interpretation, as illustrated in example (7) from Vedic Sanskrit. Certainly, it is known that passives can expand into the intransitive domain. But in this case, they generally express an impersonal meaning, typically with a dummy subject, as in German Es wird getanzt (lit.: 'It gets danced', i.e. 'There is dancing' or 'Dancing is happening'). In the Indo-Iranian case, however, there is no indication that we are dealing with an impersonal passive. For instance, example (7) features an actual subject (i.e., 'creatures'), not a dummy subject.

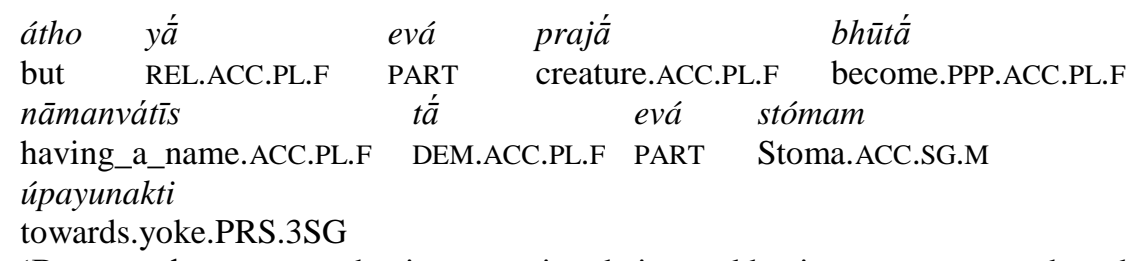

'But onto the creatures, having come into being and having a name, onto these he also harnesses the Stoma.' (MS I 5,5 (1)) 
Third, the construction is not specialized for the suppression or backgrounding of the agent. This point can, again, be illustrated with the fact that it is productively formed from intransitives which combine with various semantic roles. In the case of transitives, the agent is indeed optional. But its optionality follows from the fact that the construction is, at the outset, a subordinate structure, typically encoding secondary predicates (as in example 5). Typologically, a reduction of valency is expected for such subordinate structures.

Fourth, while the patient does indeed have subject properties, this is once more true only of cases involving transitives. In cases of intransitives, the $\mathrm{S}$ argument has subject properties, including agents in $\mathrm{S}$ function.

Fifth, a passive analysis is implausible from an information-structural perspective, as shown by Haig (2008) for Iranian. When the agent of a transitive form is expressed in Indo-Aryan and Iranian as genitive, the evidence suggests that we are dealing not with a backgrounded participant, but with a "maximally topical" (2008: 51) one. A reflection of its high topicality is the fact that we are dealing almost exclusively with pronominal arguments, as illustrated in the examples below from Vedic Sanskrit (8) and Old Persian (9). Example (9) additionally illustrates that the genitive argument can be topical enough to control co-referential deletion.

$\begin{array}{lllll}\text { utá } & \ldots & \text { sá́sya } & & \\ \text { utá } & \ldots & \text { sáa } & \text { asya } & \text { hutáivá } \\ \text { also } & \ldots & \text { DEM.NOM. } & \text { evá } \\ \text { bhavati } & & & \text { offer.PPP.NOM.SG.F } & \text { PART }\end{array}$

be.PRS.3SG

'Also, this (offering) ... is offered by him.' ( $\sqrt{\text { hav }}$ 'to offer, to sacrifice') (MS I 4,12(5))

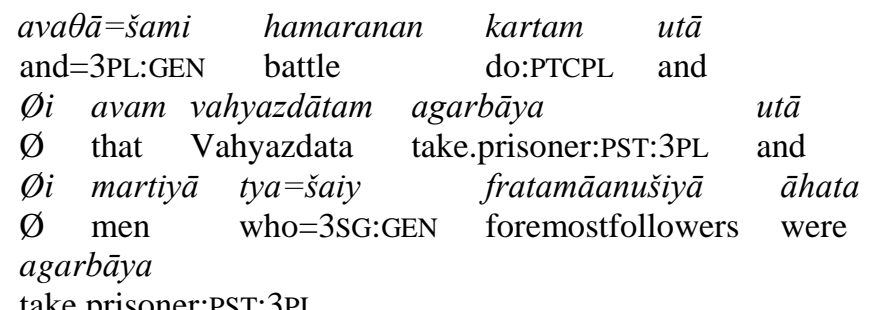

take.prisoner:PST:3PL

'They fought [lit.: made] that battle and (they) took that V. prisoner and (they) took [...] his foremost followers prisoners' ( $\sqrt{ }$ kar 'to do, make') (Haig 2008:52; glossing and translation slightly adapted)

All available evidence thus points to the same conclusion: we are not dealing with a development from passive to ergative (but rather with the development of a resultative construction from subordination to main clause perfective usage). It is worth highlighting in this context that early Indo-Iranian varieties do, in fact, have passives that tick all the boxes of the definition, e.g., the Vedic Sanskrit -ya-passive (püyáte 'is (being) purified', cf. $\bigvee p a v^{i}$ 'to purify') and the aorist passive in -i (e.g. ákāri 'was made', cf. $\sqrt{k a r}$ 'to make').

Despite our focus on Africa, we have taken some space to outline the situation in IndoIranian. As mentioned above, the origins of the passive-to-ergative hypothesis probably lie within this branch of languages and have to do with an imprecise use of the label "passive". It is therefore important to clarify that many more recent studies do not support this analysis. Furthermore, some of the arguments against a passive origin for the Indo-Iranian ergative will play a role in our analysis of Tima. While the diachronic developments are different (in particular, we do not find any evidence in Tima for an origin in a subordinate structure), the nature of some of the evidence is similar. The following points will become important: the morphological complexity (or rather simplicity) of the verb in ergative constructions; the fact that instrumental/genitive markers can develop into ergative markers outside of passive constructions; the information-structural differences to passive 
constructions; and the existence of contemporary passive constructions that bear no resemblance to ergative constructions.

\section{Case marking of postverbal agents: An areal phenomenon of languages in (north)eastern Africa}

Although ergativity is not a common phenomenon in African languages, there is one known major exception to this generalization: two subgroups from within the Nilo-Saharan family, more specifically the Saharan subgroup and the Southern branch of the Eastern Sudanic subgroup, the latter consisting of languages spoken in an area extending to the east and south of the Nuba Mountains, as well as one neighboring Koman language, Uduk (see Map 1, which is an updated version of Map 1 in Dimmendaal 2014b, taking more recent research into account). Tima is spoken at the northern fringes of this area, and it shares some salient structural properties of split case marking with other languages of this region, albeit not the actual forms. We will argue in section 4 below that language-internal changes account for the development of split ergativity in Tima. It is nevertheless likely that ancient areal contact has played an additional, facilitating, role. This section therefore gives an overview of split case marking in this area.

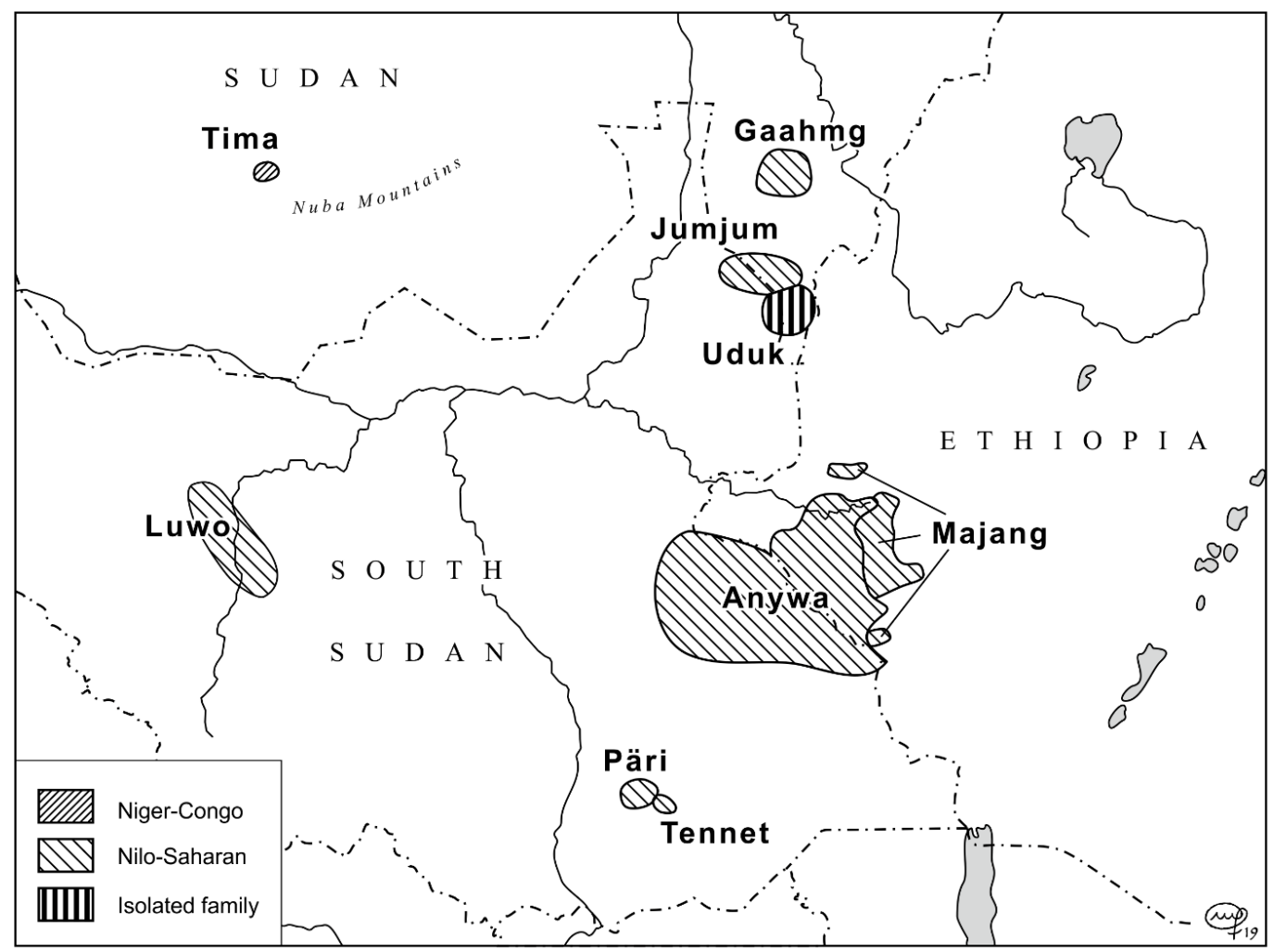

Map 1. Languages with split ergativity (Sudan, South Sudan, Ethiopia)

Split ergativity is widespread in the Southern branch of Eastern Sudanic (a sub-branch of Northeastern Nilo-Saharan; adopting the classification in Dimmendaal et al. 2019). Within Eastern Sudanic, there is a marked typological split between Northern and Southern languages. As discussed in Dimmendaal (2017: 459), "[t]he northern members of the Eastern Sudanic branch share the set of typological properties [...] [that is characteristic of Northeastern Nilo-Saharan]. But the southern members differ rather dramatically from the former." The properties of relevance to this paper are 
the following: a change of constituent order (verb-second or verb-initial, instead of verb-final), a reduced case-marking system (in particular, the absence of accusative case marking), and an innovated system of split case marking that interacts with constituent order. Some languages have even lost case marking altogether, including especially the Daju and Temeinian subgroups, as well as some languages from the Nilotic subgroup spoken in the western periphery. This situation in the Southern branch contrasts sharply with that in the Northern branch, where the languages have mostly retained the Northeastern Nilo-Saharan patterns of verb-final constituent order, with the direct object being optionally marked for accusative case (whereby the accusative case marker in most Northeastern Nilo-Saharan languages is cognate; Dimmendaal 2010a), and the subject usually remaining unmarked.

Languages from the Southern branch generally allow for both pre- and postverbal agents, whereby postverbal agents require case marking, i.e., these languages exhibit a split in case marking that correlates with the position of the agent argument. Some of the languages only allow for agents of transitive verbs to occur postverbally (thus exhibiting split ergativity, as illustrated in examples 1 to 3 in section 1), while others do not impose such a restriction (thus exhibiting a system commonly labeled "marked nominative", see König 2008: 158). The marked nominative is exemplified below for Berta: examples (10) and (11) contrast a preverbal with a postverbal intransitive subject, and examples (12) and (13) contrast a preverbal with a postverbal transitive subject - with only the postverbal intransitive and transitive subjects being tonally marked for case (labeled "subject case" in the original source). Finally, and interestingly, those languages that do not allow for postverbal agents or subjects (the Daju and Temeinian subgroups; some Nilotic languages) do not have (split) case-marking systems either.
fiyír
bùun-á-Píi
donkey run-PST1-INTR
'The donkey ran.' (Andersen 2017: 102, ex. 4a; highlighting added)

$\begin{array}{llll}\text { fúl } & \text { gúd }-\downarrow^{\downarrow} \dot{l} & \begin{array}{l}\text { fíyìr } \\ \text { houkey.SBJ }\end{array} & \theta=a ̀ j u ́ \\ \text { house.CS } & \text { [stay-PRS } & \text { PREP=stomach] }\end{array}$

'The house in which the donkey stays.' (Andersen 2017: 113, ex. 30; highlighting added)
bòygór mág-ì fìnír
young_man drive-PRS donkey
'The young man is driving the donkey.' (Andersen 2017: 127, ex. 67a; highlighting added)
finír
mág-ì
bóygòr
donkey
drive-PRS
young_man.SBJ
'The young man is driving the donkey.' (Andersen 2017: 127, ex. 67b; highlighting added)

Split ergativity is attested in the following Southern Eastern Sudanic languages: Gaahmg (the only non-extinct language from the Jebel subgroup; Stirtz 2014); Luwo (Storch 2014), Anywa (Reh 1996, who refers to this morpheme as a definiteness marker), Päri (Andersen 1988), and Jumjum (Andersen 2018), all four from the Nilotic subgroup; as well as Majang (Joswig 2019), and Tennet (Randal 1998) from the Surmic subgroup. Other languages from Southern Eastern Sudanic exhibit marked nominative systems: this includes a good number of Surmic ${ }^{3}$ and Nilotic languages,

\footnotetext{
${ }^{3}$ The question whether the alignment system of the dialect continuum Tirma-Chai (within Surmic) should be analyzed as a split ergative system was left open by Last and Lucassen (1998: 408). More recently, the in-depth
} 
but also Berta (which is most closely related to the Jebel language Gaahmg). Outside of Southern Eastern Sudanic, split ergativity is not only reported for Tima (Niger-Congo), but also for Uduk (from the Koman family, considered an independent language family together with the B'aga languages by the authors), as shown in Killian (2015). And marked nominative alignment has been reported for Katcha (Turner 2018), a language spoken in the Nuba Mountains which belongs to the Kadu family (considered an independent group by the authors). We refer the readers to Dimmendaal (2014a; 2017: 458-463) for further details.

Given this distribution across families, it is likely that the overt case marking of postverbal agents (following an ergative alignment) or postverbal subjects (following a nominative alignment) constitutes an areal phenomenon. It can no longer be reconstructed with any certainty in which subarea(s) or language(s) this phenomenon originated ${ }^{4}$ but it is likely to be of ancient origin: the development of split ergativity must have taken place at least at the level of Proto-Southern Eastern Sudanic, as we find reflexes in most of its subgroups. ${ }^{5}$ Dimmendaal (2014a; 2017: 462) assumes the case markers to be cognate: Southern Eastern Sudanic languages often exhibit an alternation between $-\varepsilon /-e$ and $-I /-i$, which in turn probably developed from two distinct case markers (instrumental and genitive respectively; both are still attested with these functions in Northern Eastern Sudanic). ${ }^{6}$ We furthermore consider it likely that case marking extended from marking transitive postverbal agents to marking all (transitive and intransitive) postverbal subjects, i.e., the ergative developed into the marked nominative. ${ }^{7}$ The evidence here comes firstly from formal marking: the ergative is usually marked by the suffixes $-\varepsilon /-e$ and $-I /-i$, while the nominative is marked by tonal inflection, i.e., it would be difficult to explain how a single tonal marking developed into two segmentally distinct suffixes. Note also that exactly the same case markers are attested in the distantly related Saharan languages - expressing ergativity, not marked nominative (Dimmendaal et al. 2019: 370). And secondly, supporting evidence comes from languages such as Tennet, which have a marked nominative system, but which have retained ergative alignment in subordinate clauses. All assumed developments are cross-linguistically well attested: the co-existence of two distinct ergative markers from different historical sources (Arkadiev 2017); instrumental and/or genitive markers developing into ergative markers (as in, e.g., Indo-Iranian; see also McGregor 2017: 447); and retention of older patterns of alignment in subordinate clauses only (Harris and Campbell 1995: 27).

Independent of the developments within Southern Eastern Sudanic, it is unlikely that the spread of ergative or marked nominative systems to other languages of the region coincided with a borrowing of forms: while the pattern of case-marking postverbal agents/subjects is stable across the region, the forms are different. That is, the (proto) languages must have recruited languageinternal material for these purposes. More specifically, Tima uses a proclitic $N=$ 'ERG', which is

\footnotetext{
investigation of the third member of this dialect continuum, Mursi, has shown that Mursi has a marked nominative system (Worku, 2020; by extension, this probably also applies to Tirma and Chai).

${ }^{4}$ Note that this also holds true for other phenomena. As Dimmendaal (2017: 466) observes, "[t]he areal source for some of the dramatic changes is not always obvious."

${ }^{5}$ And possibly already before with the last common ancestor of Eastern Sudanic and Saharan, as Saharan languages use cognate suffixes to mark ergative case. Otherwise, though, they share the Northeastern NiloSaharan patterns of accusative case marking and verb-final syntax - i.e., ergative marking is found with preverbal agents in this sub-branch. Right-dislocation does exist, though, and OVAERG constructions are thus an option, too (Bondarev et al. 2011).

${ }^{6}$ Additional forms, such as a suffix (or enclitic) - $o$ in Surmic languages like Chai (Last and Lucassen 1998: 407, and passim) presumably constitute innovations.

7 This position is also defended in Dimmendaal (2014a) and Dimmendaal et al. (2019: 370) on the basis of additional historical-comparative evidence. Similarly, Randal (2000), drawing on the genetic distribution of split ergativity within Surmic and Nilotic, concludes that Proto-Surmic had a split ergative alignment system, and that the marked nominative system was a later development. See also Dixon (1979) who refers to the "marked nominative" as "extended ergative". This view is not shared by all researchers, though, e.g., König (2012; 2017) postulates a development from marked nominative towards ergativity.
} 
highly unlikely to have any relationship to the Eastern Sudanic suffixes $-\varepsilon /-e$ and $-I /-i$. Furthermore, neither the form of the ergative marker nor the existence of postverbal agents can be traced to any of Tima's neighboring languages. Tima does share clan names with neighboring Eastern Sudanic communities such as Temein or Wali (see Dimmendaal 2015: 62, 76, 78), suggesting that contact is likely to have taken place, including possibly language shift. However, Southern Eastern Sudanic languages such as Temein belong to subgroups (i.e., Temeinian and Daju) that do not allow for postverbal agents/subjects synchronically and hence do not have any (split) case marking. And Northern Eastern Sudanic languages like Wali have retained Northeastern Nilo-Saharan properties (verb-final constituent order; accusative case marking).

While the origins can no longer be reconstructed with any certainty, it is nevertheless striking that languages from different families across the region share the salient pattern of marking postverbal agents/subjects. In Southern Eastern Sudanic, this pattern is clearly old, and while there are convincing etymological sources in the form of instrumental and genitive case markers, the exact discourse contexts that gave rise to the synchronic ergative and marked nominative constructions can no longer be reconstructed. This situation contrasts with that of Tima, where split ergativity probably emerged more recently, given that its closest relatives Katla and Julut do not share this alignment pattern (nor any other Niger-Congo language for that matter) (see Hellwig 2019 for Katla; see Nüsslein 2019 for Julut). For Tima, it is possible to offer a plausible account for the development of (split) ergativity, discussed in the following section.

\section{A Case Study of Tima}

Tima is a Niger-Congo language spoken by around 7000 speakers in the Nuba Mountains of Sudan. Together with Katla and Julut, it forms the group of Katloid languages.

The Niger-Congo languages of the Nuba Mountains are treated as a genetic grouping by Greenberg (1963), called Kordofanian, but this status has been questioned more recently by, e.g., Blench (2013), or Dimmendaal (2018). While their genetic affiliation with Niger-Congo is beyond any reasonable doubt, it is argued that the four 'Kordofanian' groups Heiban, Katloid, Rashad and Talodi probably constitute partly independent branches of this phylum.

Niger-Congo languages are typically head-marking at the clausal level, but dependentmarking by way of case is attested in a restricted number of languages in the Nuba Mountains. In the Heiban group, we find accusative case marking; see Ackerman and Moore (2013) for a detailed analysis of such a system in Moro. And in the Katloid group, we find an alignment that is unique for the Niger-Congo phylum so far. Whereas two of its members, Katla and Julut, are SV/AVO languages without case marking, the third member of the cluster, Tima, has a more flexible constituent order and an alignment system manifesting split ergativity. As summarized in section 3 above, Tima shares the salient structural properties of this system (specifically, an interaction of constituent order and ergative case marking) with other languages of the area, i.e., language contact is likely to have played some role in the development of this system. However, we cannot trace this phenomenon to any specific language, and it is likely that Tima recruited language-internal material for its expression.

Below, we first outline the synchronic properties of split ergativity in Tima, illustrating forms and functions (section 4.1). We then explore diachronic origins: Section 4.2 compares the form and distribution of the ergative construction to that of the passive construction, showing that they differ considerably. Section 4.3 then proposes an alternative diachronic account, arguing that the ergative construction developed from an active construction that introduced a cause by means of the instrumental preposition.

4.1 Split ergativity in Tima synchronically. Tima, like the other languages of the Katloid group, is generally head-marking, indexing arguments on the verb. In fact, the verb tends to be morphologically very complex. Apart from the root (which may constitute an independent word in 
the imperative singular), there is a range of possible derivational and inflectional affixes and clitics appearing in the order depicted in Table 1.

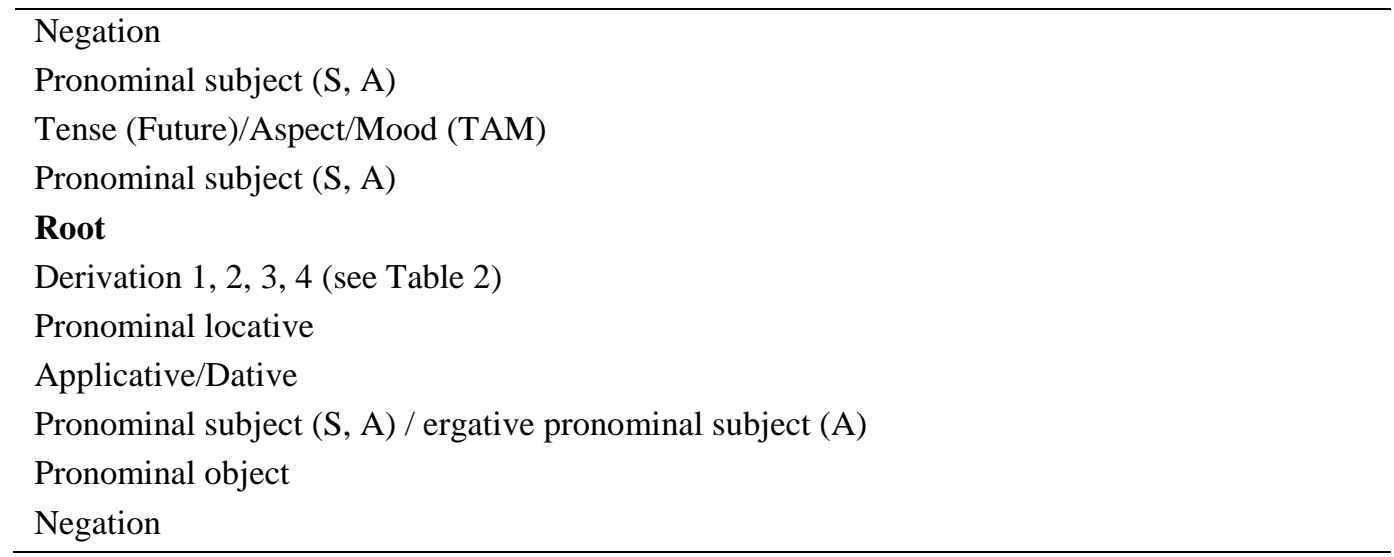

Table 1. The slots of the verbal complex

Derivational markers follow the verbal root and are sorted into four slots (see Table 2). Within each slot, the markers are mutually exclusive; across the slots, they can co-occur. Note that many of the derivational markers increase or reduce valency. Indeed, there are no ambitransitive verbs in Tima, and any changes in valency are overtly marked by derivational suffixes. This fact will become important later on for the diachronic discussion.

\begin{tabular}{l|l|l|l}
\hline Root + Slot 1 & Slot 2 & Slot 3 & Slot 4 \\
\hline & ANTIPASSIVE & & \\
ROOT-TRANSITIVE & MIDDLE & VENTIVE & INSTRUMENTAL \\
ROOT.PLURACTIONAL & CAUSATIVE & & \\
\hline
\end{tabular}

Table 2. Sequence of derivational morphemes

The core arguments of intransitive and transitive verbs are not case-marked (excepting the ergative, see below). In the case of ditransitive verbs, the indirect object, e.g., the recipient, receives a flag in the form of a proclitic (see 17 below for an example). There is only one context where both object arguments of a ditransitive expression remain unmarked: instruments, provided that the instrumental derivation $-a a$ appears on the verb (which licenses the promotion of the instrument from adjunct to core argument).

There are a number of possibilities for indexing arguments on the verb. First, Tima has a set of subject prefixes, which are cognate to those of Katla and Julut (Dimmendaal 2018: 396; see also Hellwig 2013: 240). In Tima, they usually fuse with the TAM morpheme: examples (14) and (15) illustrate a third person subject prefix in the imperfective, showing that the form is identical for $\mathrm{S}$ arguments (as in 14) and $\mathrm{A}$ arguments (as in 15).

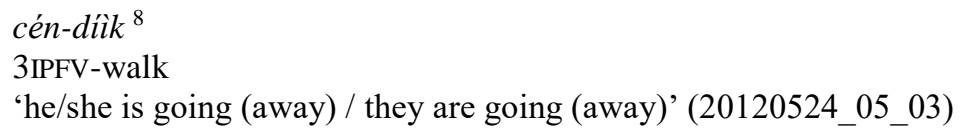

\footnotetext{
${ }^{8}$ Tima is a tone language (two level tones, two contour tones, plus downstep and upstep). A systematic investigation of the dynamics of tone is still pending, and tone marking in the examples reflects their surface realization. The Tima data used for this paper was collected between 2007 and 2019. Throughout this contribution, the source of an example sentence is noted in brackets following the free translation. The source
} 


$$
\begin{array}{ll}
\text { cén-dík } & \text { kúù } \\
\text { 3IPFV-hit } & \text { dog }
\end{array}
$$

'he/she is hitting the dog / they are hitting the dog' (20120524_11_03)

Second, there is a set of pronominal enclitics for first and second person arguments; third persons are zero. These enclitics are cognate to the Katla and Julut object forms, but Tima uses them for both subjects and objects (as illustrated in 16). Note that the subject/object enclitics can occur in either order, and the factors that trigger their relative ordering are at present unclear.

$$
\begin{aligned}
& \text { káà-hì }=d \grave{a}=\eta \grave{a} \eta=a ́ ? \\
& \text { POT2SG-know=1SG=2SG=NEG.Q } \\
& \text { 'don’t you (A) know me (O)?' (20110630_5_14) }
\end{aligned}
$$

And third, there is a special set of enclitics that indexes dative and locative arguments (illustrated in 17, where yáy 'LOC3P' indexes 'the teacher').

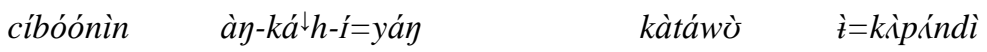

$$
\begin{aligned}
& \text { girl 3PRF-give-TR=LOC3P book DIR=teacher }
\end{aligned}
$$

'the girl gave the book to the teacher' (Skype20180418)

Note that in all focus contexts, the fused TAM/subject prefixes are absent - irrespective of which constituent is focused. Subject enclitics, by contrast, continue to be present. This phenomenon is illustrated for a focused ideophone in (18).

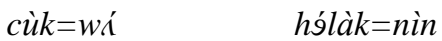

$$
\begin{aligned}
& \text { IDEO=FOC.SG stay=1PL.EXCL } \\
& \text { 'we (excl) are only sitting [not doing anything]' (20110627_7_07) }
\end{aligned}
$$

Tima allows for different constituent orders, with the constituent order SV/AVO (as in 19) arguably being basic: it is the most frequent order in elicitation contexts, and it does not require any additional indexing strategies on the verb (as is required in some alternative orders related to information packaging in a clause) or case marking on its arguments. The latter is required in the Tima ergative construction. This construction has OVAERG constituent order as well as ergative case marking of the agent. The case marker is a homorganic nasal $N=$, procliticized to the agent noun or third person pronoun (as in 20). With first and second person referents, the nasal fuses with the pronominal index, resulting in, e.g., $n i^{\prime}$ 'ERG1SG' (from $N$ 'ERG' $+d i^{\prime}$ '1SG'), and encliticizing to the preceding verb (as in 21).

$\begin{array}{lll}\text { cíbóólnín } & \text { cén-kábúh } & \text { ibún } \\ \text { girl } & \text { 3IPFV-roast } & \text { coffee } \\ \text { A } & \text { V } & \text { O }\end{array}$

'the girl is roasting coffee' (120409_01_07)

appears in different formats (reflecting the fact that data collection took place throughout various projects adhering to various conventions), but the following rough guide should help to orient the reader: elicited data only ever contains the recording date (year, month, day) plus a running number (e.g., 20120524_05_03 or 120409_01_07), natural data additionally contains a short name (e.g., 011007_11_AdlaanMisiria_Myth 003), and stimuli-based data is flagged as either "photo stimulation" (e.g., photo stimulation 160409_15_1b) or "Skopeteas" (e.g., Hamid_Skopeteas_15_1_2_D3b). In the first case, responses were elicited by means of photos from the Tima area. In the second case, responses were elicited by using tests from Skopeteas et al. (2006). 
(20)

$$
\begin{array}{lc}
{[\ldots] \text { ó-kót-ì }} & \grave{n}=\text { ihiní } \\
\text { 3P-take-TR } & \text { ERG=PRON3PL } \\
\mathrm{V} & \text { AERG } \\
\text { '[...] they take it' (040310_04_Hasabu_Granary 070) }
\end{array}
$$

$$
\begin{aligned}
& \text { gálóm } \quad c \grave{y} y-w i ́ r=\grave{a}=t a ́ n=n \dot{~} \\
& \text { pen 1SG:PRF-lose=SOURCE=LOC3P=ERG1SG } \\
& \text { O } \quad \mathrm{V}=\text { AERG }
\end{aligned}
$$

'I have lost the pen' (20180130_22)

Speakers can choose whether they want to frame a proposition by means of an AVO constituent order without case marking (as in 22) or an OVAERG order with ergative case marking (as in 23). Note that the form of the verb remains the same in both constructions, i.e., there is no difference in derivational marking (e.g., both 22 and 23 below feature the derivational suffix $-i$ 'TR') or inflectional marking (e.g., both 22 and 23 feature the subject prefix $a$ - '3PRF', conveying

\begin{tabular}{|c|c|c|}
\hline tiy. & á-hı̀mb̀̀r-ì & $\grave{j}=k \dot{u} w \grave{u} h$ \\
\hline Tiya & 3PRF-trip.up-TR & ERG=stone \\
\hline $\mathrm{O}$ & V & AERG \\
\hline
\end{tabular}
perfectivity and indexing the A AERG argument). The difference is only in constituent order and case marking on the noun.

$\begin{array}{lll}\text { kíwúh } & \text { á-hìmbìr-ì } & \text { tíyì } \\ \text { stone } & \text { 3PRF-trip.up-TR } & \text { Tiya } \\ \text { A } & \text { V } & \text { O }\end{array}$

'the stone has tripped Tiya up' (20180130_08)

'the stone has tripped Tiya up' (20180130_08)

The distribution of the two constructions is sensitive to the prominence relations between the two arguments of a transitive verb. More specifically, the more prominent argument appears in the left-most position of the clause, a position that is reserved for the topic (see below for a discussion of topichood).

An argument can be prominent on different hierarchies, e.g., it can be given (and thus high on a discourse hierarchy), or it can be animate (and thus high on an animacy hierarchy), or it can be agentive (and thus high on a semantic role hierarchy). It is possible for features from different hierarchies to cluster, resulting in a constellation where the A argument is the most prominent argument on different hierarchies (i.e., it being given, animate and agentive). Such a constellation results in an AVO constituent order without case marking. Note, however, that givenness has an impact on the realization of an argument: a given argument tends to receive a minimal expression only, e.g., it may only be indexed on the verb and not realized as an overt noun phrase, thus resulting in VO constituent order (but - importantly - we do not observe OVAERG or any other constituent order in the case of a prominent $\mathrm{A}$ argument).

Alternatively, it is possible that the features do not cluster - and this is when the ergative construction (with OVAERG constituent order) comes into play. The exact interplay between the different features and hierarchies is still only imperfectly understood, but both stimuli-based elicitation and first preliminary studies of natural data show reliably that the ergative construction is favored whenever the non-A argument increases in prominence (for details, see Schneider-Blum and Hellwig 2018; Schneider-Blum, in preparation). For example, identifiable O arguments (acted upon by only partially identifiable $\mathrm{A}$ arguments) or animate $\mathrm{O}$ arguments (acted upon by inanimate A arguments) robustly trigger the use of the ergative construction. The ergative is also preferred in cases of agent shift: the given participant (i.e., the previous agent) continues in preverbal $O$ function, 
while the new participant (i.e., the new agent) is introduced in postverbal AERG function, then becoming the topic in subsequent discourse.

In light of the above discussion, we should highlight that it is not the topic that receives ergative marking. We follow Krifka and Musan (2012: 27) and use "topic" in reference to "the entity that a speaker identifies, about which information, the comment, is then given" (see also SchultzeBerndt and Simard 2012: 1033). In this respect, the first paragraph of an overview on "[t]he grammatical development of Australian Languages" could well have been written with Tima in mind: "the unmarked grammatical slot is a natural position for the expression of the entity that is chosen as the topic or point of view [...]. Conversely, the ergative slot with its ergative marker is not such a natural position for expressing the topic" (Blake 1987: 198f). Cross-linguistically, ergative marking tends to be associated with focus, only rarely with topicality (for succinct summaries of the literature, see McGregor 2010: 1619-1620; Schultze-Berndt 2017: 1102). This is also the case in Tima, where an ergative argument cannot be topic, however, it can be focus-marked. ${ }^{9}$ Again, we follow Krifka and Musan (2012: 7) in taking focus to indicate "the presence of alternatives that are relevant for the interpretation of linguistic expressions" (see also SchultzeBerndt and Simard 2012: 1033-1034), whereby Tima has at least two overt means of doing so: selective marking (which triggers a non-exhaustive interpretation) and focus marking (which usually triggers an exhaustive interpretation, excepting some specific contexts). In the following discussion, we restrict ourselves to focus marking (for details on selective marking and its interaction with focus marking, see Becker and Schneider-Blum, submitted).

In Tima, focus is marked by means of an encliticized focus morpheme and a preverbal position of the focal constituent. Altogether, there are four options for the interaction of focus marking, case marking and constituent order in a transitive clause, illustrated in examples (24) to (30), and discussed below. All other logically possible permutations are ungrammatical. To the best of our knowledge, the topical constituent has to appear in the left-most position of the clause, i.e., we do not have evidence for the existence of right-edge topics. Recall also that givenness has an impact on the realization of an argument: an argument that is both topical and given can receive a zero realization (as in examples 25 and 29). That is, these are cases where a non-topical constituent appears in the left-most position.

Examples (24) to (26) illustrate the possibilities of focus marking involving a non-ergative A argument: these are variations of a basic AVO clause, with A being the topical constituent in the basic clause. In all cases, A remains the topical constituent in the focused clause. If the $\mathrm{O}$ argument is focal, the resulting structure is AOFOCV (as in 24). If A is both topical and given, it is not necessarily realized (e.g., it is only indexed on the verb in 25). And if the A argument is not only topical but also focal (i.e., if it is the contrastive topic, in the sense of Krifka 2007: 44), the resulting structure is AFOCVO (example 26). Essentially, the focus marking in (26) signals that there are alternatives available to the topic (i.e., non-Gwale people, in this case), answering the implicit question of "Who (of them) is doing it?"

\begin{tabular}{|c|c|c|}
\hline İ-wàrmáádśh=nă & $k-\mathrm{c}^{\downarrow} h \mathrm{u}^{\prime}{ }^{\prime} d \dot{u}={ }^{\downarrow} l i$ & $\dot{u}-k \dot{y} y \dot{~}$ \\
\hline PL-men=DEM.PROX & SG-oven=FOC.SG & 3P-do:TR \\
\hline A & OFOC & $\mathrm{V}$ \\
\hline
\end{tabular}

'these men are building an oven [and nothing else]' (photo stimulation 120409_02_09)

\footnotetext{
${ }^{9}$ In early stages of our research on Tima, we assumed a tight connection between ergativity and focus marking (as reported in König 2008: 285). However, it is now clear that these features are independent of each other: focus marking does not trigger ergative marking (and conversely, ergative constituents do not need to be focusmarked).
} 
(25)

$\begin{array}{lll}\text { tàmáá } & d \dot{u} \text {-mùrík=í=lí } & \text { nà-pólà } \\ \text { talk } & \text { MOD-Tima=SEL=FOC.SG } & \text { 2PL-want } \\ \text { OFOC } & \text { V } \\ \text { '(you) want the Tima language [and nothing else]' } & \\ \text { (011007_11_AdlaanMisiria_Myth 003) } & \end{array}$

\begin{tabular}{|c|c|c|}
\hline ìhínì=yè & kóyj̀ & $k i ̀ c i ́ y={ }^{\downarrow} n a ́$ \\
\hline $\begin{array}{l}\text { PRON3PL=FOC.PL } \\
\text { AFOC }\end{array}$ & $\begin{array}{l}\text { do:TR } \\
\text { V }\end{array}$ & ething=DEM.PROX \\
\hline
\end{tabular}

'they [the Gwale people and no-one else] do this thing (a certain feast)'

(240108_26_KanoMorto_FeastBird 033)

Examples (27) to (30) now illustrate the possibilities of focus marking involving an ergative A argument: these are variations of a basic OVAERG clause, with A being the non-topical constituent of the basic clause. In this case, A continues to be non-topical. If $\mathrm{O}$ is topical and $\mathrm{A}$ is focal, the resulting structure is OAERG\&FOCV (as in 27). Note that it is not possible for the topical $\mathrm{O}$ argument to appear in any other position, e.g., postverbally (as in the ungrammatical example 28). But, again, there is an interaction with givenness, and a given topical $\mathrm{O}$ argument can be realized as zero (as in 29). This is the only scenario where an ergative constituent appears in the left-most position. Finally, the $\mathrm{O}$ argument can be both topical and focal (i.e., a contrastive topic), in which case the structure is OFOCVAERG (as in 30).

$\begin{array}{lll}\text { cibóónín } & \grave{y}=k o ́ l o ́=\downarrow w i & k \text { kílúk } \\ \text { girl } & \text { ERG=shame=FOC.SG } & \text { eat } \\ \text { O } & \text { AERG\&FOC } & \text { V }\end{array}$

'the girl is ashamed' (more direct translation: 'shame [and nothing else] eats the girl') (060409_05_15)

\begin{tabular}{|c|c|}
\hline$* \grave{j}=k o ́ l o ́={ }^{\prime} w a ́$ & kílúk \\
\hline $\begin{array}{l}\text { ERG=shame=FOC.SG } \\
\text { AERG\&FOC }\end{array}$ & \\
\hline
\end{tabular}

$\begin{array}{ll}\grave{y}=\grave{a} k a ̀ y=\grave{a} & \grave{J}-k u^{\prime} d \dot{U} \\ \text { ERG=SOmebody=FOC.SG } & \text { PST-catch } \\ \text { AERG\&FOC } & \mathrm{V}\end{array}$

'he [and no-one else] caught (it) (the horse)'

(011007_14_AdlaanMisiria_Horsequarrel 043)

$\begin{array}{lll}\begin{array}{l}\text { ințùkúbú=yé } \\ \text { groundnuts=FOC.SG }\end{array} & \text { báàr } & \text { nìhúnèn } \\ \text { OFOC } & \text { peel } & \text { ERG:women } \\ & \mathrm{V} & \text { AERG }\end{array}$

'the women are peeling groundnuts [and nothing else]'

(photo stimulation 160409_15_1b)

This section has given a brief overview of the form and distribution of the synchronic Tima ergative construction. In the next section, we compare the synchronic ergative construction to the synchronic passive construction.

4.2 Where the Tima passive and ergative do (not) meet: Passive and ergative compared Zúñiga (2018: 13) concludes his survey of alignment type changes by stating that "an important source of alignment type change is probably the reanalysis of low-transitivity one-or two-argument clauses, 
or of nominalizations, as strict two-argument clauses [...]." One possible pathway, also discussed in Zúñiga's survey, is a passive-to-ergative analysis. This section takes a closer look at the synchronic passive construction in Tima, comparing it to the ergative construction and showing that - despite some superficial similarities - functions and forms differ considerably in the two constructions. These synchronic differences strongly suggest that they do not have the same diachronic source. Of course, it is - in theory - still possible for the Tima ergative construction to have originated in a different passive construction that has become lost, but we consider this an unlikely scenario under the circumstances.

Tima marks the passive by means of the verbal suffix -Vk (more precisely, $-V[+h i g h] k$, i.e., a high vowel preceding $k$ ). Example (31) illustrates the transitive verb wí 'lose' in active voice, and (32) illustrates its passive counterpart. Notice that the passive verb is morphologically more complex than its active counterpart (adding the passive suffix), and occurs with only one core argument (the subject), which is indexed on the verb.

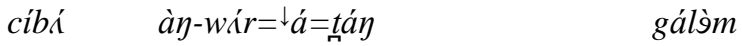

$$
\begin{aligned}
& \text { child 3PRF-lose }=\text { SOURCE }=\text { LOC3P pen } \\
& \text { A V O }
\end{aligned}
$$

'the child has lost the pen' (Skype20180523418)

$$
\begin{aligned}
& \text { gálóm à̀-wrí } r-\grave{i} k=\grave{a}=t a ́ \eta \\
& \text { pen 3PRF-lose-PASS=SOURCE }=\text { LOC3P } \\
& \text { S V }
\end{aligned}
$$

'the pen has got/been lost' (060409_14_01)

The passive suffix originated in a causative suffix (see Schneider-Blum, submitted). ${ }^{10}$ Synchronically, this suffix continues to be attested as a causativizer, as illustrated in (33) and (34). The basic intransitive verb in (33) (wúdí 'burn') is causativized by means of -ik, resulting in the transitive verb in (34b) (wùdríy'ik 'burn:CAUS'). The patient is the intransitive subject in (33) (yàáná kùtán tì̀n ìndìíli 'all things (that are) inside'), and the transitive object in (34b) (kúrtú 'house'); the

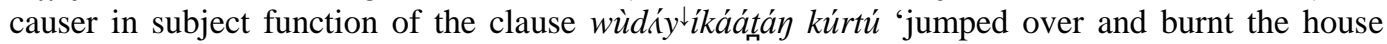
down' is realized as zero, as it is co-referential with cìní 'fire' in the preceding clause (34a).

$$
\begin{aligned}
& \text { yàáná kòtáy tìn indìníl=i céy-wúd }=\dot{a}=t a ̀ y \\
& \text { things COP:LOC3P inside all=SEL 3IPFV-burn=SOURCE=LOC3P } \\
& \text { '[all things (that are) inside]s will burn' (Hamid_Skopeteas_15_1_2_D3b) }
\end{aligned}
$$

Synchronically, the suffix $-V k$ thus has two functions: causative and passive. The distribution of the two functions across the verb lexicon differs though: a verb either allows for one

\footnotetext{
${ }^{10}$ Haspelmath (1990) sketches a possible grammaticalization path from causative via reflexive-causative to passive. Tima $-V k$ is used in all three contexts, i.e., there is language-internal evidence for the presence of the intermediate stage, too. Comparative methods lend further support to the causative meaning being the original meaning of this suffix: a presumably cognate causative (impositive) morpheme *-Ik has been reconstructed for a distantly related Niger-Congo member, Proto-Bantu, by Meeussen (1967).
} 
or the other, but never for both. While the causative occurs with a large number of (intransitive and transitive) verbs, the passive is restricted to a subset of transitive verbs.

In the passive construction, the $\mathrm{S}$ argument is the only core argument. It is possible, though, to add oblique constituents such as location (as in 35), circumstance/manner (as in 36), source (as in 37), instrument (as in 38) or accompaniment (as in 39). Interestingly, none of these facultative participants constitutes an agent phrase (see the discussion below). In fact, the Tima passive does not allow for the expression of the agent at all (as is also typical for Eastern Sudanic languages of the region).

$$
\begin{array}{llll}
\text { gálóm } & \grave{a} \eta-w{ }^{\prime} r-\grave{t} k=\grave{a}=t a ́ \eta & y \text {-ánțò } & \text { bàs } \\
\text { pen } & \text { 3PRF-lose-PASS=SOURCE=LOC3P } & \text { LOC-inside } & \text { bus } \\
\text { 'the pen has got/been lost on the bus' (Skype20180418) } &
\end{array}
$$

$$
\begin{aligned}
& \text { gálóm ày-wír-ìk=à=tán } \quad \text { Ú=kớtání } \\
& \text { pen 3PRF-lose-PASS=SOURCE=LOC3P DIR=running } \\
& \text { 'the pen has got/been lost when running' (Skype20180418) }
\end{aligned}
$$

$$
\begin{array}{lll}
\text { cèc̀-tíyíik }=n \grave{c} \dot{y} y & \text { á=bì-lil } & \text { cín } \\
\text { 1PL:PRF-shiver:PASS=1PL.INCL } & \text { SOURCE=NMLZ-cold } & \text { coldness }
\end{array}
$$

'we shivered from the cold' (Skype20180418)

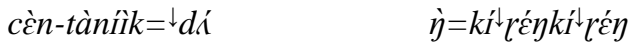

$$
\begin{aligned}
& \text { 1SG:PRF-call:PASS }=1 \mathrm{SG} \quad \text { INS=bell }
\end{aligned}
$$

'I was called/summoned by way of the bell' (Skype20180418)

$$
\begin{aligned}
& \text { kì̀ráy ám-pàr-t-ók nè̀ेhwáà } \\
& \text { field 3PRF-clean- } t \text {-PASS COM:people } \\
& \text { 'the field has been cleaned with (the help of) people' (Skype20180418) }
\end{aligned}
$$

The last three examples above could conceivably be interpreted as containing optional agent phrases (the 'cold', the 'bell' and the 'people'). However, in all three cases, we are not dealing with "agentivity in the strict sense of the term (referring to the self-controlled deliberate initiation of an action)" (DeLancey 1981: 634; see also Dowty 1991 for proto-agent features such as volitionality). This can be shown when trying to substitute the oblique participants by more agentive participants. Doing so (as in 40 and 41) will render the examples ungrammatical. This point is taken up again in section 4.3 when discussing instrumental phrases.

$$
\begin{array}{ll}
\text { *cèn-tànílk }={ }^{\downarrow} d \dot{a} & \grave{j}=\text { wárțìmáádò } h \\
\text { 1SG:PRF-call:PASS=1SG } & \text { INS=man } \\
\text { 'I was called/summoned by the man' (Skype20180418) }
\end{array}
$$

(41) *kìrán ám-pàr-t-ǵk=

field 3PRF-clean-t-PASS=INS1SG

'the field has been cleaned by me' (Skype20180418)

If an agent is to be expressed, speakers have to resort to an active construction - this can be an unmarked AVO construction, but also an ergative construction, which places the $\mathrm{O}$ argument in sentence-initial position (as in 42).

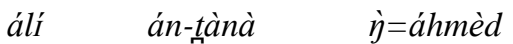

$$
\begin{aligned}
& \text { Ali 3PRF-call ERG=Ahmed } \\
& \text { 'Ahmed called Ali' (20180130_08) }
\end{aligned}
$$


Overall, the Tima passive conforms well to the cross-linguistic criteria for passives (e.g., Haig 2008: 37): the verb allows for a single core argument only (the subject), which corresponds to the object argument of the active verb; this single argument is indexed on the verb; and the passive verb is morphologically marked, specifically, it is more complex than the active form of the verb (by adding the suffix $-V k$ ); and the agent is backgrounded to the extent that it can no longer be expressed. The distribution of the passive is restricted: it is not fully productive and only occurs with a subset of transitive verbs; and it is not frequent in natural discourse. For example, a count of the - Vk suffix across 16 natural texts (763 intonation units) revealed that it most frequently occurs in its causative (47 times) and reflexive-causative functions (8 times), and only once in its passive function. Again, such a restricted distribution of passives is not uncommon cross-linguistically: they tend to be less frequent and not fully productive (see, e.g., Haspelmath 1990: 27).

Table 3 compares the synchronic properties of the Tima passive (discussed in this section) and ergative (discussed in section 4.1).

\begin{tabular}{|c|c|c|}
\hline & PASSIVE & ERGATIVE \\
\hline CONSTITUENT ORDER \& SEMANTIC ROLES & S $_{\text {PATIENT }} \mathrm{V}$ (Oblique) & $\mathrm{O}_{\text {PATIENT }} \mathrm{V} \mathrm{A}_{\text {AGENT }}$ \\
\hline $\begin{array}{l}\text { AGENT: } \\
\text { - SYNTACTIC FUNCTION } \\
\text { - MARKING OF AGENT NP } \\
\end{array}$ & $\begin{array}{l}\text { cannot be expressed } \\
\text { n/a }\end{array}$ & $\begin{array}{l}\text { A (obligatory) } \\
\text { ergative-marked }\end{array}$ \\
\hline $\begin{array}{l}\text { PATIENT: } \\
\text { - SYNTACTIC FUNCTION } \\
\text { - MARKING OF PATIENT NP } \\
\end{array}$ & $\begin{array}{l}\text { S (obligatory) } \\
\text { unmarked }\end{array}$ & $\begin{array}{l}\text { O (obligatory) } \\
\text { unmarked }\end{array}$ \\
\hline SENTENCE-INITIAL (TOPIC) POSITION & $\mathrm{S}$ & $\mathrm{O}$ \\
\hline $\begin{array}{l}\text { VERBAL MORPHOLOGY: } \\
\text { - INDEXING ON THE VERB (SUBJECT) } \\
\text { - MARKING OF PASSIVE/ERGATIVE } \\
\end{array}$ & $\begin{array}{l}\mathrm{S} \\
-V k \\
\end{array}$ & $\begin{array}{l}\text { A } \\
\text { unmarked }\end{array}$ \\
\hline PRODUCTIVITY & subset of transitive verbs & all transitive verbs \\
\hline
\end{tabular}

Table 3. The Tima passive and ergative compared

As shown in Table 3, there are both commonalities and differences across the two constructions. As in all Tima constructions, argument indexing on the verb follows a nominative/accusative pattern: the subject argument (intransitive $\mathrm{S}$ in the passive, transitive $\mathrm{A}$ in the ergative) is indexed on the verb. Furthermore, in both constructions, there are obligatory patient arguments (linked to $\mathrm{S}$ and $\mathrm{O}$ function respectively), which are morphologically unmarked and which occur in sentence-initial topic position. Formally, however, the two constructions differ in their constituent order (SV vs. OVA), in the presence of an agent role (not possible in the passive vs. obligatory in the ergative), in the morphological marking of the subject NP (unmarked S vs. ergative-marked A), and in the verbal derivational morphology (marked passive vs. unmarked ergative). Furthermore, the passive is restricted: it only occurs with a subset of transitive verbs. The ergative, by contrast, can occur with any basic or derived transitive verb.

Another way of summarizing the commonalities and differences is to say that both constructions share the discourse-pragmatic function of indicating that it is not the agent that is the topic, but the patient (see also the discussion of examples 24 to 30 above). But while they share this function, they do so by different means and for different purposes. The passive promotes the patient argument to subject function, which then exhibits the formal properties of all subjects: indexation on the verb, and - in particular - occurrence in the prominent syntactic, i.e., sentence-initial, position. This promotion has to be morphologically marked on the verb (by the suffix $-V k$ ). The agent argument is backgrounded to the extent that it cannot even be expressed: the event is portrayed 
without mentioning any agent. In elicitation sessions, speakers explicitly remark that the presence of an agent is understood, though, but that this agent is either unknown or irrelevant. ${ }^{11}$

The ergative, by contrast, promotes the patient argument to the syntactically prominent sentence-initial position, but does not change its grammatical function. This promotion has no consequence for the subject relation (i.e., the A argument continues to be indexed on the verb) nor is the promotion morphologically marked on the verb by means of derivational suffixes. The agent appears in the less prominent position (following the verb) - but, importantly, it is not unknown or irrelevant: it is obligatory, it is indexed on the verb, and it can even be marked for focus (as in examples 27 to 29 in section 4.1). In fact, we observe that AERG occurs commonly in contexts of agent shift, with the agent argument becoming the topic of the next utterance. This seemingly paradox situation can be resolved by taking into account two types of prominence: inherent and established (Schultze-Berndt 2018). In an ergative construction, the patient is inherently prominent (due to it being given, animate or having some agentivity features), and thus appears in the prominent sentence-initial position. The agent, by contrast, is inherently less prominent (it is not given and/or it is not animate and/or it has only few agentivity features). By using the ergative, speakers can signal that the agent argument will become prominent in subsequent discourse (e.g., it becoming the topic), i.e., speakers use the ergative to establish the agent argument as prominent.

These (synchronic) differences notwithstanding, it would still be possible to postulate a diachronic link between the two constructions, or alternatively between the present-day ergative and a former passive no longer attested in the language (assuming that it would have been a typical passive, i.e., it would have had similar properties to those of the present-day passive). The main argument in favor of such an origin is the form of the ergative marker $N=$, which is identical to that of the instrumental marker $N=$ (see section 4.3). The argument would then run along the following lines: The oblique constituent in the passive also admitted agent roles (introduced by instrumental $N=$ ), which later became the obligatory (ergative) A argument. In the course of development, this agent argument assumed subject properties (e.g., being indexed on the verb) while the patient argument lost them. In addition, the verb lost its passive morphology without a trace. At the same time, discourse-pragmatic changes accompanied the formal changes. While this scenario perhaps cannot be ruled out with absolute certainty, it does not seem very likely on several accounts. In particular, it postulates a number of changes for which we do not have any language-internal or comparative evidence: we would still need to identify the contexts that allowed for the development and loss of subject properties, as well as for the loss of passive morphology; and likewise, we would need to identify contexts that allowed for the change in discourse function.

4.3 Origins of the Tima ergative Section 4.2 has compared passive and ergative constructions, showing that their considerable formal and functional differences make a passive-to-ergative analysis highly unlikely: the synchronic passive construction cannot be the origin of the ergative; and an origin in another, earlier, passive construction (that is lost synchronically) is similarly unlikely. For Tima, we can thus state with a considerable degree of certainty that the passive-toergative scenario is unsubstantiated. In this section, we now want to go one step further and explore whether there are alternative, more plausible, diachronic scenarios available. Our starting point is the fact that Tima overtly marks any change in transitivity by means of derivational morphemes on the verb (see Table 2 in section 4.1). That is, we have to assume a source construction that allowed for the re-analysis of a (peripheral) participant as a core (ergative) argument without a change in transitivity. Synchronically, there are two such constructions - both of them active - that meet this criterion. In this section, we investigate the formal, semantic and discourse-pragmatic properties of these two synchronic constructions, with a view to assessing the likelihood of either of them, or both, being a possible source for the ergative. There do remain unresolved issues, as we cannot, of course, be certain of their diachronic properties; and as we have to posit bridging contexts that are not attested synchronically. Throughout the discussion, we strive to be as transparent as possible,

${ }^{11}$ To indicate a change of state without implying the existence of an agent, Tima uses - $V l$ 'middle voice'. 
explicitly highlighting all problematic aspects of the posited diachronic changes. Despite the existing unresolved issues, we consider either construction to be a more likely source construction for the Tima ergative than the passive construction.

Any diachronic scenario has to take into account that the form of the Tima ergative marker $N=$ is identical to that of the instrumental marker $N=$. We assume a common source (see Dimmendaal 2010b), also because etymological identity of agent and instrument marking is "extremely common" (DeLancey 1981: 634). Synchronically, they constitute two distinct morphemes that cannot be equaled: the instrumental marker introduces an (optional) oblique phrase, while the ergative marker introduces an (obligatory) core argument; the ergative participant is indexed on the verb, but not the instrumental participant; there are ergative pronominal enclitics, but no corresponding instrumental enclitics; ergative marking co-occurs with specific constituent order configurations; and the object may occur between the verb and an instrumental phrase, but not between the verb and the ergative A argument.

Diachronically, however, it is likely that they had a common origin. The present-day instrumental marker $N=$ has a large number of functions, including the marking of causes. We argue here that it is this function that most likely allowed for the re-interpretation of an oblique constituent as an (ergative) core argument. To avoid any misunderstanding at this point: this scenario does not necessitate a passive-to-ergative analysis, as we will outline in this section.

The instrumental marker $N=$ is used to designate the instrument or means by which something is done (in 43), as well as an inanimate companion (as the 'bread' in 44). Note that animate companions take comitative $n a=/ n \Lambda=$, not instrumental $N=$. The instrumental is furthermore used to form manner adverbials (from nominal or adjectival bases) that modify the predicate (as in 45).

$$
\begin{aligned}
& \text { kí-tiÍn=í àn-kúbí-y-úk=á=tán kínc̀ } \quad \grave{n}=t o ́ o ̀ p \\
& \text { SG-one }=\text { SEL } 3 \text { PRF-cover-EP-CAUS=SOURCE }=\text { LOC3P mouth INS=toop } \\
& \text { 'one (of the two women) is covering her mouth with a toop (traditional Sudanese cloth)' } \\
& \text { (120409_08_12) }
\end{aligned}
$$

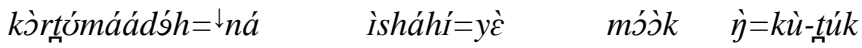

$$
\begin{aligned}
& \text { man=DEM.PROX PL:tea=FOC.PL drink INS=SG-bread } \\
& \text { 'this man is drinking tea with bread' (130409_05_08) }
\end{aligned}
$$

$$
\begin{aligned}
& \text { à-tókóm }=\grave{a}=t a ́ n \quad \quad \grave{n}=k \dot{n}-m a ́ l \\
& \text { 2SG-mix=SOURCE=LOC3P INS=SG-good } \\
& \text { 'you mix it well' (040310_04_Hasabu_Granary 043) }
\end{aligned}
$$

The above three examples illustrate uses that are commonly subsumed in instrumental-type case markers and adpositions (Stolz et al. 2006). In addition, the instrumental is used to introduce less-affected participants. For example, in (46), the interpretation is that the bark is not fully pulled off, i.e., it is not fully affected. If it were fully affected, this participant would occur as an unmarked direct object, without instrumental marking.

$$
\begin{aligned}
& k \text {-ícúk, i-tñh }=n \grave{c} \varepsilon \dot{y} \quad \quad \grave{j}=k w a ́ a ́ h \\
& \text { SG-baobab 1PL-pull:PLUR=1PL.INCL INS=SG:bark } \\
& \text { '(as for the) baobab, we pull (at) the bark' (310108_33, use of plants (Adlaan): 26) }
\end{aligned}
$$

And, of most interest for our argument, the instrumental is regularly used to indicate the cause of an event, as illustrated in examples (47) and (48) below. 


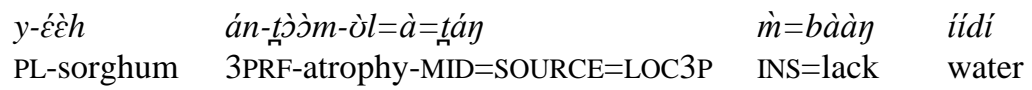

'the sorghum has become atrophic due to (lit.: by/with) lack of water' (070409_2_02_11)

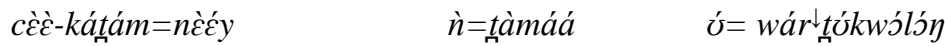

$$
\begin{aligned}
& \text { 1PL:PRF-leave=1PL.INCL INS=speech DIR=elder }
\end{aligned}
$$

'we left because of (lit.: by/with) the words of the elder' (Skype20180418)

We have already seen this function of the instrumental in the passive example (38) (section 4.2), repeated in (49) for convenience.

$$
\begin{aligned}
& \text { cغ̀n-tàní́k }={ }^{\downarrow} d \dot{~} \\
& \text { 1SG:PRF-call:PASS=1SG }
\end{aligned}
$$

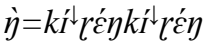

$$
\begin{aligned}
& \text { 'I was called/summoned by way of the bell' (Skype20180418) }
\end{aligned}
$$

The instrumental phrase, both in active and passive sentences, can thus express a causing event: the lack of water in (47), the speech of the elder in (48), or the ringing of the bell in (49). Following Dowty (1991), we take causation to be a proto-agent feature: a typical agent is one who causes an event or change of state in another participant (while, conversely, a typical patient is causally affected by another participant). It is this proto-agent feature that is present in instrumental phrases. By contrast, another important proto-agent feature, volitionality, is not present (see the ungrammatical examples 40 and 41 in section 4.2). Note also that the event in (48) above is framed as being caused metonymically by 'the speech of the elder' - not by 'the elder'. In fact, there is no single example in the database with a straightforward human causer.

We assume that it is this causal use that motivated the development of the ergative marker. That is, we assume a shift from ' $\mathrm{X}$ happens because of $\mathrm{Y}$ ' to ' $\mathrm{Y}$ causes $\mathrm{X}$ '. Tima, indeed, does allow for causes to occur as A arguments. Compare example (50) below (with the causing event as A argument) to the contrastive example (48) above (with the causing event in an instrumental phrase). As always, the A argument can either be unmarked for case (as in 50), or marked for ergative case (as in 51).

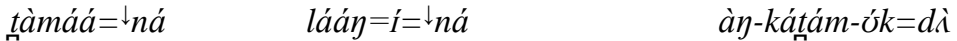

$$
\begin{aligned}
& \text { talk=DEM.PROX } \quad \text { 2SG.POSS }=\text { SEL }=\text { DEM.PROX } \quad 3 \text { PRF-leave-CAUS }=1 \mathrm{SG} \\
& \text { A } \\
& \text { 'your speech made me leave' (Skype20190523) }
\end{aligned}
$$

$\begin{array}{lll}\text { háámít } & \text { à } \eta \text {-káttám-ók } & \grave{n=t a ̀ m a ́ a ́}={ }^{\natural} \text { ná } \\ \text { Haamid } & \text { 3PRF-leave-CAUS } & \text { ERG=talk=DEM.PROX } \\ \mathrm{O} & \mathrm{V} & \text { AERG }\end{array}$

Semantically, such a shift (from expressing the cause within an oblique constituent to expressing it in a core constituent) is plausible and it is supported by the fact that present-day Tima allows causing events as core constituents, i.e., as A arguments. But note that, in present-day Tima, such a shift necessitates a change in verbal morphology. For example, the basic intransitive verb kátám 'leave' is used together with the instrumental phrase in (48), but the derived transitive verb kátámók 'make leave' has to be used when the cause appears as A argument (as in 50 and 51). That is, it is unlikely that the re-interpretation of instrumental $N=$ as ergative $N=$ occurred in the context 
of the intransitive verb plus prepositional phrase construction exemplified in (48) (or 47 and 49 for that matter): if this were the case, we would expect the verb forms in (48) and (51) to be identical. ${ }^{12}$

By contrast, if we assume that the re-interpretation took place in a transitive context, we are able to explain why the verb forms in AVO PPINS and OVAERG constructions are identical: in the absence of a change in transitivity, the verb forms remain identical. But while such an origin thus has its advantages, it creates another problem: a transitive context already has an A argument, making it difficult to account for the re-analysis of an oblique instrument as an A argument. However, there are two (transitive) contexts in the present-day language that are promising candidates for such a re-analysis: (i) the antipassive construction, and (ii) a three-participant context involving an instrument. Given the lack of attested historical sources, it is impossible to decide with confidence on one scenario to the exclusion of the other. We also do not deny that there remain problematic aspects (and we point them out throughout the discussion), but we consider either scenario more promising than if we assumed a passive origin - for which we cannot posit any bridging contexts.

Context (i): Tima has an antipassive construction that serves to reduce the transitivity of a verb. Although this construction has a fairly specialized function, it occurs with reasonable frequency in Tima discourse, thus making it a possible candidate for the source construction: in a corpus of 16 natural texts (763 intonation units), it occurred 61 times (similar to other derivations such as, e.g., the causative derivation, which occurred 47 times).

In its basic function, the antipassive marker $-a k /-\wedge k$ detransitivizes a transitive verb. For example, (52) features a transitive verb occurring with an object argument, and the corresponding example (53) illustrates this verb marked for antipassive. In the latter case, the verb is intransitive, and it is no longer possible to add the object argument cititi 'cloth'. As always, though, it is possible to add a cause in an instrumental phrase (as in 54).

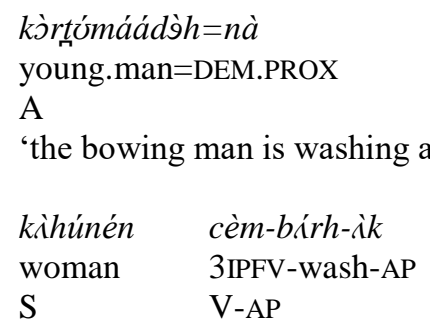

'the woman is washing' (Skype20190523)

\begin{tabular}{|c|c|c|c|c|}
\hline kìhúnén & cèm-bírh-ikk & $\grave{m}=b a \grave{a} y$ & 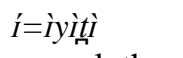 & ídìíl \\
\hline woman & 3IPFV-wash-AP & INS=lack & $\mathrm{DIR}=$ clothes & clean \\
\hline S & V-AP & PP(INS) & & \\
\hline
\end{tabular}

\footnotetext{
${ }^{12}$ As pointed out by an anonymous reviewer, this change in verb form may be only a minor complication in the sense that it could be explained by positing an analogical extension from causativized verbs to all transitive verbs at a later stage. As such, it would still be possible to argue for a development from [S V PP(INS)] (as in 48) to [O VCAus AERG] (as in 51): the causativization of an intransitive verb, the re-interpretation of the instrument/cause as the agent, and the patient remaining in preverbal position (but changing its function from $\mathrm{S}$ to $\mathrm{O}$ ). While we cannot rule out this possibility, we consider the synchronic evidence to speak against such a scenario. First, the causative derivation would initially still require an overt A argument, i.e., the steps would have to be from [S V PP(INS)] via [A VCAUS O PP(INS)] to [VCAUS O AERG] - which adds an extra step to one of our proposed diachronic scenarios (see point ii). And second, as the reviewer points out, such a scenario would be facilitated in a context where the agent is focused or unexpected. But synchronically, focused arguments obligatorily occur in preverbal position, i.e., we would have to assume the initial stages of the development to be from [PP(INS) S V] to [AERG O VCAUS], which does not align with the synchronic constituent order of the ergative construction (see also footnote 14).
} 
Interestingly, and in spite of the fact that Tima also has a separate middle voice marker, the antipassive has a second function: the expression of a reflexive/autobenefactive (as well as malefactive) function. In this case, the verb can co-occur with a direct object. A typical example with a sentient, volitionally acting, agent is illustrated in (55) - with the agent being co-referential with the beneficiary. But the agent can also be inanimate (as in 56 and 57). And, as in all transitive constructions, the agent can occur both in the unmarked AVO construction (as in 56) and in the ergative OVAERG construction (as in 57).

\begin{tabular}{|c|c|c|}
\hline trúúdèl & à $\eta-k{ }^{\prime} t{ }^{\prime} \gamma-a ́ k=\dot{a}=t a ́ \eta$ & kàtáwò \\
\hline Trudel & 3PRF-take.along-AP=SOURCE $=\mathrm{LOC} 3 \mathrm{P}$ & book \\
\hline A & V-AP & $\mathrm{O}$ \\
\hline
\end{tabular}

'Trudel took the book along (with her)' (070310_07_05)

$\begin{array}{lll}\text { iídi } & \text { ày-kơtớ } C \text {-ák=á=táy } & \text { háámìt } \\ \text { water } & \text { 3PRF-take.along-AP=SOURCE=LOC3P } & \text { Hamid } \\ \text { A } & \text { V-AP } & \text { O }\end{array}$

'Hamid drowned (lit.: the water took Hamid along)' (070310_07_04)

\begin{tabular}{|c|c|c|}
\hline háámít & 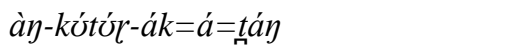 & $\grave{j}$-íldi \\
\hline Hamid & 3PRF-take.along-AP-SOURCE $=$ LOC3P & $E R G=$ water \\
\hline $\mathrm{O}$ & V-AP & AERG \\
\hline
\end{tabular}

'Hamid drowned (lit.: the water took Hamid along)' (070310_07_04)

In the present-day language, a verb usually either allows for the detransitivizing function of the antipassive marker (exemplified here with the help of birh 'wash' in 52 to 54) or for the reflexive/autobenefactive function (exemplified with kưtór 'take along' in 55 to 57), but usually not for both. Diachronically, we would have to assume that the construction with the reflexive/autobenefactive function was still an intransitive construction: a verb such as kưtór 'take along' was marked for antipassive and co-occurred with an oblique instrumental phrase introducing

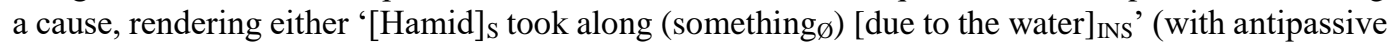
function; in parallel to 54 above) or '[Hamid] $]_{S}$ took along (self $\varnothing$ ) [due to the water] $]_{\mathrm{INS}}$ ' (with reflexive/autobenefactive function; in parallel to 55). The re-interpretation as an ergative construction must then have taken place in the reflexive/autobenefactive context, with the cause in the oblique phrase becoming re-interpreted as the causing agent (i.e., [the water $]_{\mathrm{A}}$ caused $[\mathrm{Hamid}]_{\mathrm{O}}$ to take along (selfø)) (as in 57). ${ }^{13}$

Such a scenario would be in line with the cross-linguistic observation that ergatives frequently develop from constructions with reduced transitivity, albeit not (necessarily) from passives. For Tima, such a scenario has the advantage that it can explain the morphological makeup of the verb: both the intransitive source construction (in parallel to 54 above) and the transitive ergative construction (as in 57) contain the same antipassive morphology. Once established, the ergative construction must then have spread to other transitive verbs, regardless of them being marked or not marked for the antipassive (see Harris and Campbell 1995: 97-119 for the process of "extension" in historical syntax).

The main objection would be that it is not immediately obvious how to account for the shift in agreement: the instrumental phrase is not indexed on the verb (e.g., in 54 above, the index cèm'3IPFV' picks out the $\mathrm{S}$ argument, 'the woman'), while the ergative argument is indexed (e.g., in 57 above, the index $\grave{a} y$ - '3PRF' picks out the ergative A argument, 'the water'). That is, we still need to

\footnotetext{
${ }^{13}$ While we are not aware that this exact scenario is attested elsewhere, it has been argued, for instance for some Australian and some Austronesian languages, that antipassives can be stepping stones for a shift from ergative to accusative alignment (see references in Yanagida 2007). On the diachronic development of noncanonical subjects more generally, see Seržant and Kulikov (2013).
} 
explain how the instrumental phrase acquired subject properties, and how the $\mathrm{S}$ argument lost them. We come back to this issue at the end of this section.

Context (ii): Alternatively, or in addition, the re-interpretation could have taken place in the context of three-participant events that included instruments. Example (58) illustrates such a case: a transitive verb with a subject and object noun phrase, plus an instrument added in a prepositional phrase in the right periphery. In connected discourse, it is very rare for all three noun phrases to be overtly expressed, and a given A argument tends to be realized as zero (illustrated in example 59, with $\emptyset$ marking the place where we would expect it to occur). In the present-day language, the instrument can either appear as an oblique constituent (as in 58 and 59), or as a core constituent in A function (as in 60 and 61) (see also 48, 50 and 51 above for causing events showing the same alternation). As always, the A argument can either be postverbal and marked for ergative case (as in 60) or preverbal and unmarked for case (as in 61).

$\begin{array}{lllll}\text { kìhúnén } & \text { àn-tćtćk=á=táy } & \text { yábòh } & \grave{m}=\text { pòkàà } & \text { kíhćkér } \\ \text { woman } & \text { 3PRF-chop=SOURCE=LOC3P } & \text { meat } & \text { INS=knife } & \text { sharp } \\ \text { A } & \mathrm{V} & \mathrm{O} & \mathrm{PP}(\mathrm{INS}) & \end{array}$

'the woman cut the meat with a sharp knife' (Skype20190523)

$\begin{array}{lllll}\varnothing & \text { àn-tćtćk=á=táy } & \text { yábòh } & \grave{m}=\text { pòkàà } & \text { kíhćkćr } \\ \varnothing & \text { 3PRF-chop=SOURCE=LOC3P } & \text { meat } & \text { INS=knife } & \text { sharp } \\ \text { (A) } & \mathrm{V} & \mathrm{O} & \mathrm{PP}(\mathrm{INS}) & \end{array}$

'(she) cut the meat with a sharp knife' (Skype20190523)

$(60)$

$\begin{array}{llll}\text { yábớh } & \text { àn-tćtćk=á=tán } & \grave{m}=\text { pòkàà } & \text { kíhćkér } \\ \text { meat } & \text { 3PRF-chop=SOURCE=LOC3P } & \text { ERG=knife } & \text { sharp } \\ \text { O } & \mathrm{V} & \text { AERG } & \\ \text { 'the sharp knife cut the meat' (Skype20190523) } & \end{array}$

\begin{tabular}{|c|c|c|c|}
\hline pòkàà & kíhékér & àn-tćtćk=á=tá & yábòh \\
\hline knife & sharp & 3 PRF-chop $=$ SOURCE $=$ LOC $3 \mathrm{P}$ & meat \\
\hline $\begin{array}{l}\text { A } \\
\text { "the }\end{array}$ & & $\begin{array}{l}\text { V } \\
\text { 't' (Skyne20190523) }\end{array}$ & $\mathrm{O}$ \\
\hline
\end{tabular}

The re-interpretation of the instrument as an ergative would then have taken place in the context exemplified in (59): the zero realization of the original agent ('the woman') was reinterpreted as the absence of this argument (see also Mithun 2005: 85 for a comparable proposal for the development of the ergative in Coosan languages), triggering two further changes. First, the A function was assigned to the instrument, i.e., to the participant that is ranked highest on the semantic role hierarchy (in the absence of an agent), thus accounting for the instrumental-cum-ergative proclitic on the A argument as well as its postverbal position. Second, a topicalization process ${ }^{14}$ led

\footnotetext{
${ }^{14}$ An alternative possibility, suggested to us by an anonymous reviewer, would be that the extension of instrumental marking to ergative marking took place in the context of focused instruments/agents. To the best of our knowledge, the synchronic evidence does not support such a scenario. In the present-day language, focused constituents occur in preverbal position, and this includes focused ergative A arguments (see the discussion of examples 27 to 29 in section 4.1). That is, we would have to assume a focused instrumental phrase to occur in preverbal position, too (and thereby allowing for instrumental marking to extend to focused agents in the same preverbal slot). In the present-day language, however, this is not possible: oblique instrumental phrases cannot occur preverbally, not even if focus-marked. This would only be possible when the instrument is promoted to core argument status (i.e., $\mathrm{O}$ argument) by means of the verbal instrumental derivation. Recall also that focus contexts involve a reduced form of the verb, without TAM/subject marking (see the discussion of example 18 in section 4.1), i.e., we would expect there to be some traces of this reduced verb form in the present-day ergative construction.
} 
to a change in constituent order, with the $\mathrm{O}$ now appearing in preverbal position. As briefly summarized in section 4.1 , we observe that topic selection, synchronically, is sensitive to the prominence relations between $\mathrm{A}$ and $\mathrm{O}$. Assuming that the same sensitivity held at earlier stages of the language, a less agentive A argument (such as an instrument or cause that is non-sentient and that does not act volitionally) would facilitate the selection of the $\mathrm{O}$ argument as topic. Synchronically, the change in constituent order makes it possible to unambiguously identify pòkàà kíh $k_{k}$ 'r 'the sharp knife' as the oblique instrument in (59), and as the ergative agent in (60). Otherwise, the instrumental and ergative constructions in (59) and (60) would look identical, making this structure the ideal context for the re-interpretation and the development of the ergative.

Under either scenario, the diachronic origin in an instrumental phrase continues to be visible in the synchronic distribution of the ergative construction: the ergative is favored in cases of causing, non-volitional, agents (i.e., in cases where the A argument exhibits only the proto-agent feature of causation, but not volition, sentience, or independent movement). This is illustrated in (62) (repeated from 23 above). And, under either scenario, the use of the instrumental as agent markers then extended to contexts where the agent has further proto-agent features, in particular, volitionality. In present-day Tima, an ergative argument can be human and can act volitionally (as shown in 63), but does not need to (as shown in 62).

$$
\begin{array}{lll}
\text { tíyí } & \dot{a} \text {-hìmbìr-ì } & \grave{y}=\text { kর́wùh } \\
\text { Tiya } & \text { 3PRF-trip.up-TR } & \text { ERG=stone } \\
\text { 'the stone tripped Tiya up' (20180130_08) }
\end{array}
$$

$\begin{array}{lll}\text { kìcímbíri } & \text { àn-táán } & \grave{y}=\text { kìhúnèn } \\ \text { child } & \text { 3PRF-beat } & \text { ERG=woman }\end{array}$

'the woman has beaten the child' (190207_56)

Given the absence of attested diachronic materials, the above accounts have to remain of necessity speculative to some extent. However, we do maintain that these accounts go a long way to explain most of the properties of the Tima ergative construction: the postverbal position of the ergative argument and the preverbal position of the object argument, the presence of the instrumental-cum-ergative proclitic on the agent, the absence of any overt ('ergative') morphology on the verb, and the importance of the proto-agent feature 'causation'.

The main unresolved issue is the development of subject properties of the peripheral argument (i.e., it being indexed on the verb). It is possible that such a shift took place in the context of both participants being 3rd persons: e.g., the 3rd person index ày- '3PRF' on the verb in (57) could conceivably index either 'Hamid' or 'the water'. It is only when substituting different person categories that it becomes clear that, in the present-day language, it can only ever index the ergativemarked agent. Under such a scenario, there must have been a time when ày- '3PRF' was ambiguous as to whether it indexed 'Hamid' or 'the water' - eventually, this ambiguity was then resolved in favor of the argument exhibiting Dowty's (1991) proto-agent feature of causation, i.e., 'the water'. In any case, it is likely that subject agreement was a late development, triggered by the extension of instrumental marking from instruments/causes (as in 62) to more prototypical agents exhibiting more proto-agent features (as in 63).

Although rare, such shifts in agreement are attested for other languages (see Harris and Campbell 1995: 240-281). For Tima, there is one indication that some form of alignment change may have taken place. The evidence comes from comparing argument indexes and pronominal arguments within the Katloid group of languages. It is likely that the Katloid languages originally had subject prefixes/proclitics and object suffixes/enclitics, as these can be reconstructed for their common ancestor on the basis of cognate forms (Dimmendaal 2018: 395-396). In addition, however, Tima (unlike Katla and Julut) has pronominal subject enclitics, as in example (49) above. Interestingly, the form of the subject enclitics is identical to that of the object enclitics in Tima, as well as cognate to the object suffixes/enclitics in Katla and Julut. Given the form and position of the 
subject enclitics, it is likely that - in certain contexts - (pronominal) object arguments were reinterpreted as (pronominal) subject arguments. At present, we cannot offer any specifics about these contexts, nor can we link them to the development of the ergative construction. But the comparative evidence suggests that the development of subject properties of the ergative argument may have to be seen in the light of a more general alignment change in Tima.

\section{Conclusion}

The aim of this paper is to contribute to on-going debates about the origins of ergativity, and especially to the widespread hypothesis of the passive origin of ergative constructions. It focuses on a case study of Tima, where the instrumental proclitic $N=$ became re-interpreted as the ergative proclitic $N=$. The paper suggests two possible contexts for this re-interpretation: both of them active constructions, with $N=$ introducing a cause or instrument in an oblique phrase, and with a subsequent re-interpretation of this oblique (instrumental) participant as the causing (ergative) agent. As discussed in detail in section 4, either account can explain a good number of the synchronic properties of the Tima ergative construction. We do acknowledge that there remain unresolved issues, especially regarding the development of subject properties, but we do hope to have shown that the postulated bridging contexts are plausible contexts in the light of comparable synchronic constructions. And, more specifically, that they constitute a more plausible origin than a passive construction. If we assume a passive origin, we would have to identify not only the contexts that allowed for the development of subject properties of the agent by-phrase, but also those that enabled the complete loss of passive/ergative morphology on the verb (without leaving any traces synchronically) as well as those that triggered the change in discourse-pragmatic function. Synchronically, the discourse-pragmatic functions of the ergative construction are different from those of the passive and similar to those of the active. As discussed in section 4.2, the passive eliminates the agent, which is irrelevant or unknown. Ergative and non-ergative active constructions, by contrast, reflect the prominence relations between the two arguments of a transitive verb: the more prominent the patient (on one of the prominence hierarchies), the greater the likelihood for the ergative - but the agent is neither irrelevant nor unknown.

As summarized in section 2, Indo-Iranian also fails to deliver supporting evidence for a passive-to-ergative analysis. Although it has been argued that passives developed into ergatives in that sub-family, with historical sources allegedly attesting to such a development, various specialists of Indo-Iranian have been arguing that such an analysis cannot be upheld, accumulating evidence that the source construction has not been a passive.

On the one hand, language-internal evidence does not point towards a passive origin, nor is there a cross-linguistic tendency that would support a passive-to-ergative analysis. And on the other hand, we can offer alternative origins in active constructions. Given the available evidence, we consider a passive origin for the Tima ergative highly unlikely. We have similar skepticism about a passive origin for other languages of the region, amongst others, because several of these languages have formally distinct passive constructions. As discussed in section 3, salient structural properties of split case marking are shared by languages from different families across the entire area: languages exhibiting either split ergativity (marking postverbal agents) or marked nominative (marking postverbal subjects). In light of the Tima and Indo-Iranian evidence, we would urge to not take the passive-to-ergative hypothesis for granted and instead examine the language-internal evidence on a case-by-case basis. 


\section{Abbreviations}

\begin{tabular}{|c|c|}
\hline $1,2,3$ & $1^{\text {st }}, 2^{\text {nd }}, 3^{\text {rd }}$ (person $)$ \\
\hline $3 \mathrm{~S}$ & $3^{\text {rd }}$ person singular \\
\hline A & subject of transitive clause \\
\hline ACC & accusative \\
\hline $\mathrm{AP}$ & antipassive \\
\hline $\mathrm{C}$ & completive \\
\hline CAUS & causative \\
\hline $\mathrm{COM}$ & comitative \\
\hline $\mathrm{COP}$ & copula \\
\hline $\mathrm{CS}$ & construct state \\
\hline DEM & demonstrative \\
\hline DIR & direction \\
\hline EP & epenthetic element \\
\hline ERG & ergative \\
\hline EXCL & exclusive \\
\hline $\mathrm{F}$ & feminine \\
\hline FOC & focus \\
\hline GEN & genitive \\
\hline IDEO & ideophone \\
\hline IMP & imperative \\
\hline INCL & inclusive \\
\hline INS & instrumental \\
\hline INTR & intransitive \\
\hline IPFV & imperfective \\
\hline LOC & locative \\
\hline LP & local particle \\
\hline M & masculine \\
\hline MID & middle \\
\hline MOD & modifying \\
\hline $\mathrm{N}$ & neuter \\
\hline NEG & negative \\
\hline
\end{tabular}

$\begin{array}{ll}\text { NMLZ } & \text { nominalizer } \\ \text { NOM } & \text { nominative } \\ \text { O } & \text { object } \\ \text { P } & \text { person } \\ \text { PART } & \text { particle } \\ \text { PASS } & \text { passive } \\ \text { PL } & \text { plural } \\ \text { PLUR } & \text { pluractional } \\ \text { POSS } & \text { possessive } \\ \text { POT } & \text { potential } \\ \text { PP } & \text { prepositional phrase } \\ \text { PPP } & \text { past passive participle } \\ \text { PREP } & \text { preposition } \\ \text { PRON } & \text { pronoun } \\ \text { PRF } & \text { perfect } \\ \text { PROX } & \text { proximal } \\ \text { PRS } & \text { present } \\ \text { PST } & \text { past } \\ \text { PST1 } & \text { past tense suffix }-a \\ \text { PTCPL } & \text { participle } \\ \text { Q } & \text { question marker } \\ \text { REF } & \text { referential } \\ \text { REL } & \text { relative } \\ \text { S } & \text { subject of intransitive clause } \\ \text { SBJ } & \text { subjective } \\ \text { SEL } & \text { selective } \\ \text { SG } & \text { singular } \\ \text { SOURCE } & \text { source marker } \\ \text { TR } & \text { transitive } \\ \text { V } & \text { verb } \\ \text { VOC } & \text { vocative } \\ & \end{array}$

\section{Acknowledgements \& Author contribution}

Our research on Tima started in 2006, and our sincere thanks go to the many Tima speakers who invested considerable time and effort to help construct the documentary corpus for this research. We gratefully acknowledge the funding by the Deutsche Forschungsgemeinschaft (DFG, German Research Foundation; Project-ID 281511265 - SFB 1252, 2017-2021 / Project-ID 406074683 Emmy Noether Project, Uta Reinöhl, 2019-2024), the University of Cologne (through its Leo Spitzer Prize awarded to Gerrit Dimmendaal, 2014-2017) and the DobeS program of the Volkswagen Foundation (2006-2012). We would also like to take the opportunity to thank our colleagues at the SFB for fruitful discussions of the arguments presented in this paper as well as James Essegbey and two anonymous reviewers for their valuable comments on earlier versions of this paper.

This paper constitutes joint work by all 5 authors, reflected in the alphabetical ordering of our names. BH undertook most of the actual writing, based on earlier drafts by AC and UR (section 2, on Indo-Aryan and Iranian), GD (section 3) and GSB (section 4). But such a division of labor does not accurately reflect the individual contributions: the line of argumentation was developed jointly in discussions and revisions of each other's drafts, such that it is no longer possible to neatly assign authorship to any one section, and - crucially - each author contributed their unique 
perspectives. It is fair to say that the paper would look substantially different if any one of the authors had not been involved.

\section{References}

Ackerman, Farrell \& John Moore. 2013. Objects in Moro. In Thilo C. Schadeberg \& Roger M. Blench (eds.), Nuba Mountain Language Studies, 83-103. Cologne: Köppe.

Aldridge, Edith. 2017. Intransitivity and the development of ergative alignment. In Jessica Coon, Diane Massam \& Lisa Demena Travis (eds.), The Oxford Handbook of Ergativity, 501-529. Oxford: Oxford University Press.

Andersen, Torben. 1988. Ergativity in Päri, a Nilotic OVS language. Lingua 75, 289-324.

Andersen, Torben. 2017. Clause-internal antitopics in Berta, a Nilo-Saharan verb-second language. Studies in Language 41:1, 99-141.

Andersen, Torben. 2018. The encoding of subjects and objects in Jumjum, a Nilotic OV language. Lingua 204, 78-216.

Arkadiev, Peter. 2017. Multiple ergatives: From allomorphy to differential agent marking. Studies in Language 41:3, 717-780.

Becker, Laura \& Gertrud Schneider-Blum. Submitted. Morphological marking of contrast in Tima.

Benveniste, Emile. 1952. La construction passive du parfait transitif. Bulletin de la Société de Linguistique de Paris 48, 52-62.

Blake, Barry, J. 1987. The grammatical development of Australian languages. Lingua 71, 179201.

Blench, Roger M. 2013. Does Kordofanian constitute a group and if not, where do its languages fit into Niger-Congo? In Thilo C. Schadeberg \& Roger M. Blench (eds.), Nuba Mountain Language Studies, 571-586. Cologne: Köppe.

Bondarev, D., Jaggar, P. J., Löhr, D. \& Tijani, A. I. 2011. Differential subject marking in Kanuri: agentivity, pragmatics, and split-intransitive. In Doris Löhr, Eva Rothmaler \& Georg Ziegelmeyer (eds.), Kanuri, Borno and Beyond: Current Studies on the Lake Chad Region, 27-57. Cologne: Köppe.

Buth, Randall. 1981. Ergative word order - Luwo is OVS. Occasional Papers in the Study of the Sudanese Languages 1, 74-90.

Casaretto, Antje \& Uta Reinöhl. Submitted. Identifying discourse functions without formal clues Secondary predicates and related functions in Vedic Sanskrit.

Creissels, Denis \& Jeff Good. 2018. Current issues in African morphosyntax: Introduction. In Tom Güldemann (ed.), The Languages and Linguistics of Africa, 709-711. Berlin: De Gruyter Mouton.

Dahl, Eystein \& Krzysztof Stroński (eds.). 2016. Indo-Aryan Ergativity in Typological and Diachronic Perspective. Amsterdam: Benjamins.

DeLancey, Scott. 1981. An interpretation of split ergativity and related patterns. Language 57:3, 626-657.

Dimmendaal, Gerrit J. 2010a. Differential object marking in Nilo-Saharan. Journal of African Languages and Linguistics 31, 13-46.

Dimmendaal, Gerrit J. 2010b. On the origin of ergativity in Tima. In Frank Floricic (ed.), Essais de Typologie et de Linguistique Générale: Mélanges Offerts à Denis Creissels, 233-239. Paris: Presses Universitaires de l'École Normale Superieure. 
Dimmendaal, Gerrit J. 2014a. Marked nominative systems in Eastern Sudanic and their historical origin. Afrikanistik Online 11. (urn:nbn:de:0009-10-38596)

Dimmendaal, Gerrit J. 2014b. Where have all the noun classes gone in Tima. In Carole de Féral, Maarten Kossmann \& Mauro Tosco (eds.), In and out of Africa: Languages in Question in Honour of Robert Nicolaï Vol. 2: Contact and Language Change in Africa, 104-124.

Louvain-La-Neuve - Walpole, MA: Peeters.

Dimmendaal, Gerrit, J. 2015. The Leopard's Spots: Essays on Language, Cognition and Culture. Leiden: Brill.

Dimmendaal, Gerrit J. 2017. Areal contact in Nilo-Saharan. In Raymond Hickey (ed.), Cambridge Handbook of Areal Linguistics, 446-470. Cambridge: Cambridge University Press.

Dimmendaal, Gerrit J. 2018. Reconstructing Katloid and deconstructing Kordofanian. In Gertrud Schneider-Blum, Birgit Hellwig \& Gerrit J. Dimmendaal (eds.), Nuba Mountain Language Studies: New Insights, 383-415. Cologne: Köppe.

Dimmendaal, Gerrit J., Colleen Ahland, Angelika Jakobi \& Constance Kutsch Lojenga. 2019. Linguistic features and typologies in languages commonly referred to as 'Nilo-Saharan'. In Ekkehard Wolff (ed.), Cambridge Handbook of African Languages, 326-381. Cambridge: Cambridge University Press.

Dixon, R. M. W. 1979. Ergativity. Language 55: 59-138.

Dowty, David. 1991. Thematic proto-roles and argument selection. Language 67:3, 547-619.

Greenberg, Joseph H. 1963 (1966). The Languages of Africa. Bloomington: Indiana University Press \& The Hague: Mouton.

Haig, Geoffrey L.J. 2008. Alignment Change in Iranian Languages. A Construction Grammar Approach. Berlin: De Gruyter Mouton.

Harris, Alice C. \& Lyle Campbell. 1995. Historical Syntax in Cross-Linguistic Perspective. Cambridge: Cambridge University Press.

Haspelmath, Martin. 1990. The grammaticization of passive morphology. Studies in Language $14: 1,25-72$.

Hellwig, Birgit. 2013. Verbal morphology in Katla. In Thilo C. Schadeberg \& Roger M. Blench (eds.), Nuba Mountain Language Studies, 237-250. Cologne: Köppe.

Hellwig, Birgit. 2019. Grammatical relations in Katla. In Alena Witzlack-Makarevich \& Balthasar Bickel (eds.), Argument Selectors: A New Perspective on Grammatical Relations, 511-531. Amsterdam: Benjamins.

Hock, Hans Henrich. 1986. 'P-oriented' constructions in Sanskrit. In Bhadriraju Krishnamurti, Colin P. Masica \& Anjani K. Sinha (eds.). South Asian Languages: Structure, Convergence and Diglossia, 15-26. Delhi: Motilal Banarsidass.

Jamison, Stephanie W. 1979. The case of the agent in Indo-European. Die Sprache 25, 129-143.

Joswig, Andreas. 2019. The Majang Language. Amsterdam: Netherlands Graduate School of Linguistics.

Killian, Don. 2015. Topics in Uduk Phonology and Morphosyntax. PhD thesis. University of Helsinki.

Klaiman, Myriam H. 1978. Arguments against a passive origin of the IA ergative. Papers from the 14th Regional Meeting of the Chicago Linguistic Society, 204-216. Chicago, IL: University of Chicago Press.

König, Christa. 2008. Case in Africa. Oxford: Oxford University Press.

König, Christa. 2012. On the rise of ergative structures in Africa. In Osamu Hieda (ed.),

Challenges in Nilotic Linguistics and More, Phonology, Morphology and Syntax, 27-45.

Fuchu, Tokyo: Research Institute for Languages and Cultures of Asia and Africa. 
König, Christa. 2017. Ergativity in Africa. In Jessica Coon, Diane Massam \& Lisa Demena Travis (eds.), The Oxford Handbook of Ergativity, 900-923. Oxford: Oxford University Press.

Krifka, Manfred. 2007. Basic notions of information structure. In Caroline Féry, Gisbert Fanselow \& Manfred Krifka (eds.), The Notions of Information Structure - Interdisciplinary Studies on Information Structure, Vol. 6 (2007), 13-55. Potsdam: Universitätsverlag.

Krifka, Manfred \& Renate Musan. (2012). Information structure: Overview and linguistic issues. In Manfred Krifka \& Renate Musan (eds.), The Expression of Information Structure, 1-44. Berlin: De Gruyter Mouton.

Last, Marco \& Deborah Lucassen. 1998. A grammatical sketch of Chai, a Southeastern Surmic language. In Gerrit J. Dimmendaal \& Marco Last (eds.), Surmic Languages and Cultures, 375-436. Cologne: Köppe.

McGregor, William B. 2010. Optional ergative case marking systems in a typological-semiotic perspective. Lingua 120:7, 1610-1636.

McGregor, William B. 2017. Grammaticalization of ergative case marking. In Jessica Coon, Diane Massam \& Lisa Demena Travis (eds.), The Oxford Handbook of Ergativity, 447-464. Oxford: Oxford University Press.

Meeussen, A. E. 1967. Bantu grammatical reconstructions. Africana Linguistica 1967:3, 79-121. (Available online at https://www.persee.fr/doc/aflin_2033-8732_1967_num_3_1_873 (accessed on 2018/07/27).)

Mithun, Marianne. 2005. Ergativity and language contact on the Oregon Coast: Alsea, Siuslaw, and Coos. Proceedings of the Berkeley Linguistics Society 26, 77-95.

Nüsslein, Ulrike. 2019. Description and documentation of Julut with particular consideration of the verbal morphology. PhD thesis. Universität Erfurt.

Peterson, John M. 1998. Grammatical Relations in Pāli and the Emergence of Ergativity in IndoAryan. München/Newcastle: Lincom Europa.

Randal, Scott. 1998. A grammatical sketch of Tennet. In Gerrit J. Dimmendaal \& Marco Last (eds.), 219-272. Surmic Languages and Cultures. Cologne: Köppe.

Randal, Scott. 2000. Tennet's ergative origins. Occasional Papers in the Study of Sudanese Languages 8: 67-80.

Reh, Mechthild. 1996. Anywa Language: Description and Internal Reconstructions. Cologne: Köppe.

Reinöhl, Uta. 2018. Review of Eystein Dahl \& Krzysztof Stroński (eds.). 2016. Indo-Aryan ergativity in typological and diachronic perspective. Journal of South Asian Languages and Linguistics 5:1, 111-121.

Remijsen, Bert \& Otto Gwado Ayoker. 2018. A descriptive grammar of Shilluk. Language Documentation and Conservation, SP14.

Schneider-Blum, Gertrud. In preparation. The impact of attentional centering on ergative marking in Tima.

Schneider-Blum, Gertrud. Submitted. Around causation in Tima.

Schneider-Blum, Gertrud \& Birgit Hellwig. 2018. Reference tracking in Tima and its interplay with split ergative marking. Studies in Language 42:4, 970-993.

Schultze-Berndt, Eva. 2017. Interaction of ergativity and information structure in Jaminjung (Australia). In Jessica Coon, Diane Massam \& Lisa Demena Travis (eds.), The Oxford Handbook of Ergativity, 1089-1113. Oxford: Oxford University Press.

Schultze-Berndt, Eva. 2018. Universal vs. language-specific influences on agent prominence and differential agent marking: a view from Down Under. Talk presented at the Second International Conference "Prominence in Language", University of Cologne, 11 July 2018. 
Schultze-Berndt, Eva \& Candide Simard. 2012. Constraints on noun phrase discontinuity in an Australian Language: The role of prosody and information structure. Linguistics 50.5: 10151058.

Seržant, Ilja A. \& Leonid Kulikov. 2013. The Diachronic Typology of Non-Canonical Subjects. Amsterdam: Benjamins.

Skopeteas, Stavros, Ines Fiedler, Sam Hellmuth et al. 2006. Questionnaire on Information Structure. Reference Manual. Potsdam: Universitätsverlag.

Stirtz, Timothy. 2014. Ergative, antipassive and other verb derivational morphemes in Gaahmg. Journal of African Languages and Linguistics 35: 243-272.

Stolz, Thomas, Cornelia Stroh \& Aina Urdze. 2006. On Comitatives and Related Categories: A Typological Study with Special Focus on the Languages of Europe. Berlin: De Gruyter Mouton.

Storch, Anne. 2014. A Grammar of Luwo. An Anthropological Approach. Amsterdam: Benjamins.

Turner, Darryl. 2018. Prepositions and pronominal case in Katcha. In Gertrud Schneider-Blum, Birgit Hellwig, \& Gerrit J. Dimmendaal (eds.), Nuba Mountain Language Studies: New Insights, 15-35. Cologne: Köppe.

Van Valin, Robert D. \& Randy J. LaPolla. 1997. Syntax: Structure, Meaning, and Function. Cambridge: Cambridge University Press.

Worku, Firew Girma. 2020. A Grammar of Mursi. PhD thesis. James Cook University, Cairns.

Yanagida, Yuko. 2007. Miyagawa's (1989) exceptions: An ergative analysis. In Yoichi Miamoto (ed.), MIT Working Papers in Linguistics 55, 265-276.

Zúñiga, Fernando. 2018. The diachrony of morphosyntactic alignment. Linguistics Compass 12:e12300. (https://doi.org/10.1111/lnc3.12300)

Antje Casaretto <antje.casaretto@uni-koeln.de>

Birgit Hellwig <bhellwig@uni-koeln.de>

Department of Linguistics

University of Cologne

50923 Cologne

Germany

Gerrit J. Dimmendaal <gerrit.dimmendaal@uni-koeln.de>

Gertrud Schneider-Blum <gschnei4@uni-koeln.de>

Institute for African Studies and Egyptology

University of Cologne

50923 Cologne

Germany

Uta Reinöhl <uta.reinoehl@linguistik.uni-freiburg.de>

Sprachwissenschaftliches Seminar

Albert-Ludwigs-Universität Freiburg

79085 Freiburg im Breisgau

Germany 